\title{
Alcoholic Extract of Eclipta alba Shows In Vitro Antioxidant and Anticancer Activity without Exhibiting Toxicological Effects
}

\author{
Navneet Kumar Yadav, ${ }^{1}$ Rakesh Kumar Arya, ${ }^{2}$ Kapil Dev, ${ }^{3}$ \\ Chetan Sharma, ${ }^{3}$ Zakir Hossain, ${ }^{4}$ Sanjeev Meena, ${ }^{2,5}$ K. R. Arya, ${ }^{3,5}$ J. R. Gayen, ${ }^{4,5}$ \\ Dipak Datta, ${ }^{2,5}$ and R. K. Singh ${ }^{1,5}$ \\ ${ }^{1}$ Toxicology Division, CSIR-Central Drug Research Institute, Lucknow 226031, India \\ ${ }^{2}$ Biochemistry Division, CSIR-Central Drug Research Institute, Lucknow 226031, India \\ ${ }^{3}$ Botany Division, CSIR-Central Drug Research Institute, Lucknow 226031, India \\ ${ }^{4}$ Pharmacokinetics and Metabolism Division, CSIR-Central Drug Research Institute, Lucknow 226031, India \\ ${ }^{5}$ Academy of Scientific and Innovative Research (AcSIR), Anusandhan Bhawan, New Delhi 110001, India
}

Correspondence should be addressed to Dipak Datta; dipak.datta@cdri.res.in and R. K. Singh; rk_singh@cdri.res.in

Received 21 May 2016; Revised 5 September 2016; Accepted 4 October 2016; Published 31 January 2017

Academic Editor: Giuseppe Cirillo

Copyright (C) 2017 Navneet Kumar Yadav et al. This is an open access article distributed under the Creative Commons Attribution License, which permits unrestricted use, distribution, and reproduction in any medium, provided the original work is properly cited.

As per WHO estimates, $80 \%$ of people around the world use medicinal plants for the cure and prevention of various diseases including cancer owing to their easy availability and cost effectiveness. Eclipta alba has long been used in Ayurveda to treat liver diseases, eye ailments, and hair related disorders. The promising medicinal value of E. alba prompted us to study the antioxidant, nontoxic, and anticancer potential of its alcoholic extract. In the current study, we evaluated the in vitro cytotoxic and antioxidant effect of the alcoholic extract of Eclipta alba (AEEA) in multiple cancer cell lines along with control. We have also evaluated its effect on different in vivo toxicity parameters. Here, we found that AEEA was found to be most active in most of the cancer cell lines but it significantly induced apoptosis in human breast cancer cell lines by disrupting mitochondrial membrane potential and DNA damage. Moreover, AEEA treatment inhibited migration in both MCF 7 and MDA-MB-231 cells in a dose dependent manner. Further, AEEA possesses robust in vitro antioxidant activity along with high total phenolic and flavonoid contents. In summary, our results indicate that Eclipta alba has enormous potential in complementary and alternative medicine for the treatment of cancer.

\section{Introduction}

Cancer is one of the most frequently occurring diseases causing 8.2 million deaths in 2012 worldwide. Further breast cancer is the most often diagnosed cancer in females and the leading cause of cancer related death worldwide, with an estimated 1.7 million new cases and 522,000 deaths around the world in 2012. There has been a great advancement in cancer treatment which enhanced the patient survival and quality of life. However, cancer related deaths are continuously rising [1-3].

Medicinal plants exhibit a wide range of biological properties for combating human diseases. A large number of medicinal plants were utilized all over the world for prevention and treatments of diseases [4]. Use of herbal medicine for the treatment of breast cancer and other types of cancer has been well reported in scientific literature [5-9]. Moreover, plant based medicines also have an enormous potential to provide low cost, easily accessible, and safe method of treatment $[10,11]$. Herbal medicines are widely accepted in complementary and alternative medicine especially in cancer patients with poor socioeconomic condition. Hundreds of plants possessing anticancer properties have been identified, and they are the source of alternative medicine for cancer therapy in various regions of the globe [12-14]. However, a large number of plant species remain to be screened for their therapeutic potential; therefore, they can be used as a continuous source of new medicines for present and future health problems of humans including cancer. 
Medicinal plants are also playing an important role in drug discovery and have been exploited for effective and beneficial uses against cancer, as both preventive and therapeutic strategies [13]. Generally prescribed chemotherapy drugs show very narrow therapeutic indexes and are known to cause severe side effects involving nausea, loss of taste, fatigue, loss of hair, immunosuppression, loss of libido, and myelosuppression, whereas herbal medicines are expected to have lesser undesirable effects in comparison to synthetic compounds and chemotherapeutic drugs $[4-7,15]$. Herbal medicines provide us with relatively safe, effective, and economical therapeutic options, especially in the context of cancer in developing countries [16]. The nontoxic mode of antitumor activity of medicinal plants has been associated with their ability to selectively trigger multiple cell death pathways and thus induced apoptosis in cancer cells, sparing normal cells alive $[17,18]$.

Eclipta alba (L.) Hassk (synonym Eclipta prostrata) is an annual herbaceous plant, erect or prostrate, belonging to the Asteraceae family. It is also known as Bhringaraj in Ayurveda which has been generally utilized for a very long time as a part of conventional prescription for ailments especially related to the liver and hair. There are four main varieties of the herb Eclipta alba based on the colour of their blossom, that is, red, yellow, white, and blue. The white and yellow ones assume an essential part in traditional medicine, but it is the white species (Eclipta alba) that is most commonly harvested for its therapeutic advantages as it grows wildly in moist places, as a weed, and it can be easily propagated. The extracts from the leaves and flowers of this medicinal herb can be applied in numerous ways, both topically and internally, to soothe many ailments.

In the Ayurvedic system of medicine, Eclipta alba was used to maintain the balance of Vata and Kapha and described as medicinal herb for the treatment of liver diseases [19]. In China, it has been traditionally used as a food additive and herbal medicine to cure infectious hepatitis, liver cirrhosis, abnormal uterine bleeding, jaundice, hematuria and diarrhea with bloody stools, epistaxis, aching and weakness of the knees and loins, and spitting of blood [20-23]. Eclipta alba shows versatile pharmacological effects that include hair growth, antimicrobial, antioxidant, anti-inflammatory, analgesic, antinociceptive, antileprotic, antihaemorrhagic, antimyotoxic, antiviral, antihepatotoxic, diuretic, hypotensive, hypocholesterolemic, hypotensive, immunomodulatory, nootropic, ovicidal, and spasmogenic activity [24-34].

Hepatoprotective activity of Eclipta alba is well described in literature [33, 35-38]. In Indian systems of medicines herbal decoction of Eclipta alba is used for the treatment of liver cirrhosis, infective hepatitis (liver inflammation due to a viral infection), liver enlargement, and other related diseases of liver and gall bladder [39-42]. Various scientific studies reported that Eclipta alba shows protective effects in rats and mice against $\mathrm{CCl}_{4}$-induced liver damage. Its protective activity against liver injury and inflammation produced the effects on subcellular levels [19, 36, 39]. Eclipta alba have been traditionally used as a hair growth promoter and several scientific studies also confirmed this potential [25, 33, 34, 43, 44]. Eclipta alba acts as an important exogenous mediator that stimulates follicular keratinocyte proliferation and delays terminal differentiation by downregulating TGF$\beta 1$ expression. Thus it can be used in treatment of certain types of alopecia [45].

Lirdprapamongkol et al., 2008, first reported the inhibitory effects of Eclipta alba on invasion, migration, and adhesion of cancer cells. Further, they also determined the antiangiogenic activity by using chick chorioallantoic membrane assay [46]. Chaudhary et al., 2011, showed cytotoxic effects of Eclipta alba on HepG2 (human liver), A498 (rat kidney), and C6 (rat glioma) cell lines [47]. They also reported in vitro and in vivo multidrug resistance reversal potential of Eclipta alba on hepatocellular carcinoma [48, 49]. Chauhan et al., 2012, and Liu et al., 2012, described its anticancer activity on human hepatocarcinoma cell line (SMMC-7721) and human lung epithelial adenocarcinoma cell line (HCC-827), respectively [22, 32]. Ali et al., 2014, reported its chemopreventive effects on skin carcinogenesis [50]. Further, Kim et al., 2015, and Cho et al., 2016, showed the growth inhibitory effects of Eclipta alba constituents on ovarian cancer cells [51, 52].

Reactive oxygen species (ROS) plays a critical role in inducing antitumor effects in most of the herbal medications. At the optimum level, ROS acts as a prosurvival factor, whereas high level of ROS is responsible for irreversible damage to DNA, protein, and lipids, resulting in cell death through various ways, including necrosis and apoptosis [53-55]. In the case of stress, ROS increased beyond its normal level causing serious injury to cellular system and subsequently gave rise to many diseases such as diabetes, atherosclerosis, inflammation, aging, cardiovascular diseases, and cancer [56]. Thus, equilibrium in ROS level is very important for normal body function. Numbers of phytocompounds present in medicinal plant extracts have potent antioxidant property. Multiple reports have described the ROS scavenging activity of various phytocompounds and plant extract. Hence, they can be used for protective activity against ROS mediated damage [57-59].

Although anticancer properties of Eclipta alba extract have recently been reported, here, we have reported the anti-breast cancer activity of alcoholic extract of Eclipta alba (AEEA) along with its antioxidant activity and in vivo toxicity study. Results of anticancer and antioxidant study will be crucial for understanding the role of AEEA in breast cancer therapy. In vivo study was conducted to evaluate the safety of AEEA administrated orally. Outcomes of this study will be helpful in advancement of knowledge regarding any unwanted side effects associated with use of AEEA in therapy.

\section{Materials and Methods}

2.1. Ethics Statement. All animal procedures have been approved and prior permission from the Institutional Animal Ethical Committee (IAEC) was obtained as per the prescribed guidelines.

2.2. Reagents. Hoechst 33342 and Rhodamine 123 were obtained from Sigma Aldrich. Annexin V Alexa Fluor 488 was procured from Molecular Probes-Invitrogen. All chemicals 
and antibodies were obtained from Sigma unless specified otherwise.

2.3. Plant Material. Eclipta alba was collected and the sample was authenticated by Dr. K. R. Arya, Principal Scientist, Botany Division, CSIR-Central Drug Research Institute Lucknow (UP), India. Specimen sample of Eclipta alba has been allotted a voucher sample specimen number KRA/2275 and kept at the medicinal plant repository of the institute.

2.4. Preparation of Eclipta alba Extract. The Eclipta alba was dried in an oven at $40^{\circ} \mathrm{C}$ for 5 days and then ground in an electric blender. The powder was suspended in $80 \%$ alcohol and left at room temperature for $24 \mathrm{~h}$. The crude extract was filtered using $125 \mathrm{~mm}$ Whatman ${ }^{\circledR}$ qualitative filter paper under sterile condition. This process was repeated 5 times and then the solvent (alcoholic extract of Eclipta alba), thus collected, was evaporated to dryness under reduced pressure using a rotary evaporator below $50^{\circ} \mathrm{C}$. Residues were further subjected to dryness by incubating them for 8 days at $37^{\circ} \mathrm{C}$ and extract was kept at $4^{\circ} \mathrm{C}$ until use. The yield of the extract was $12.5 \%(\mathrm{w} / \mathrm{w})$.

2.5. Quantification of Total Phenol and Total Flavonoid. Total phenol content of the samples was determined by FolinCiocalteu's calorimetric method as described by Singleton and Rossi, 1965 [60]. Folin-Ciocalteu reagent reduced the samples containing polyphenols producing blue coloured complex. Quantification was carried out on the basis of the standard curve of gallic acid prepared in $80 \%(\mathrm{v} / \mathrm{v})$ methanol. To prepare a calibration curve, $100 \mu \mathrm{L}$ aliquots of $12.5,25,50,100,200$, and $400 \mu \mathrm{g} / \mathrm{mL}$ methanolic gallic acid solutions were mixed with $250 \mu \mathrm{L}$ Folin-Ciocalteu reagent (diluted tenfold) and $250 \mu \mathrm{L}$ (7.5\%) sodium bicarbonate. After incubation at $25^{\circ} \mathrm{C}$ for $30 \mathrm{~min}$, absorbance was taken at $765 \mathrm{~nm}$ against blank by UV spectrophotometer. The same procedure was applied for the samples as described above in the preparation of calibration curve.

Total flavonoid content (TFC) was determined using aluminium chloride colourimetric method described by Chang et al., 2002 [61]. Results were expressed as mg quercetin equivalent/g dry weight (DW). The calibration curve was prepared using standard quercetin compound at concentrations of $(12.5-400 \mu \mathrm{g} / \mathrm{mL})$ in methanol. $0.5 \mathrm{~mL}$ of each plant extract in methanol was separately mixed with $1.5 \mathrm{~mL}$ of methanol, $0.1 \mathrm{~mL}$ of $10 \%$ aluminium chloride, $0.1 \mathrm{~mL}$ of $1 \mathrm{M}$ potassium acetate, and $2.8 \mathrm{~mL}$ of distilled water. After the incubation of the reaction mixture at room temperature for $30 \mathrm{~min}$, the absorbance was determined using spectrophotometer at $\lambda_{\max }=415 \mathrm{~nm}$ against the blank solution. All measurements were performed in triplicate and results of TPC and TFC were expressed in $\mathrm{mg}$ gallic acid equivalent (GAE) and mg quercetin equivalent (QUE) per gram of dry weight of sample, respectively.

2.6. In Vitro Antioxidant Activity and Free Radical Scavenging Capacity. Stock solution of each sample was prepared in a concentration of $1 \mathrm{mg} / \mathrm{mL}$. Standard (i.e., ascorbic acid and quercetin) was used for comparison in all assays. The absorbance at the respective wavelengths was recorded using a UV-vis spectrophotometer and the measurements were run in triplicate.

2.7. Total Antioxidant Capacity. Total antioxidant activity of the AEEA was evaluated by the phosphomolybdate assay (Prieto et al., 1999), with slight modifications [62]. An aliquot of $0.5 \mathrm{~mL}$ of extract solution was added to $5 \mathrm{~mL}$ of reagent solution $(0.6 \mathrm{M}$ sulfuric acid, $28 \mathrm{mM}$ sodium phosphate, and $4 \mathrm{mM}$ ammonium molybdate). The reaction solutions were allowed to incubate in boiling water bath at $90^{\circ} \mathrm{C}$ for 90 min. After cooling the samples at room temperature, the absorbance of the solution was measured at $695 \mathrm{~nm}$ against blank using a spectrophotometer. The same method was used for blank sample and $0.5 \mathrm{~mL}$ methanol is used instead of extract. Total antioxidant capacity was calculated using the standard graph of ascorbic acid. Results are expressed as equivalent of ascorbic acid in mg per gram of extract.

2.8. DPPH Radical Scavenging Activity. The antioxidant activity of the AEEA was measured in terms of hydrogen donating ability using the traditional DPPH assay of BrandWilliams et al., 1995, with slight modifications [63]. $0.5 \mathrm{~mL}$ of each sample and control at various concentrations (3.125$100 \mu \mathrm{g} / \mathrm{mL}$ ) was added to $1.5 \mathrm{~mL}$ DPPH $(0.004 \%)$ solution and allowed to stand in the dark at room temperature for $20 \mathrm{~min}$. The absorbance at $517 \mathrm{~nm}$ was recorded using a UV-vis spectrophotometer and results are expressed in $\mathrm{mM}$ ascorbic acid equivalent (AAE) per g dry weight of sample. The percentage of inhibition of DPPH free radical scavenging activity was calculated using the following equation:

$$
\% \text { inhibition }=\left[\frac{\left(A_{\mathrm{DPPH}}-A_{\text {sample }}\right)}{A_{\mathrm{DPPH}}}\right] \times 100,
$$

where $A_{\mathrm{DPPH}}$ is absorbance of DPPH and $A_{\text {sample }}$ is absorbance of sample (extract/ascorbic acid).

2.9. Nitric Oxide Free Radical Scavenging Activity. To measure the nitric oxide free radical scavenging activity, $0.1 \mathrm{~mL}$ of plant extract of different concentration dissolved in DMSO was taken and then methanol was added to make the volume $150 \mu \mathrm{L} .2 .0 \mathrm{~mL}$ of sodium nitroprusside $(10 \mathrm{mM})$ in phosphate buffer saline was added in each tube and all samples were incubated at room temperature for 150 minutes. After the incubation, $5 \mathrm{~mL}$ of Griess reagent was added to each tube and the absorbance of chromophore formed was measured at $546 \mathrm{~nm}$ on spectrophotometer. Same procedure was repeated with standard ascorbic acid and methanol (blank which served as control) $[64,65]$. The percentage scavenging activity was calculated using the following equation:

$$
\% \text { Scavenging }=\left[\frac{A_{\text {control }}-A_{\text {sample }}}{A_{\text {control }}}\right] \times 100,
$$

where $A_{\text {control }}$ is absorbance of control and $A_{\text {sample }}$ is absorbance of sample (extract/ascorbic acid). 
2.10. Lipid Peroxidation Inhibition Activity. MDA assay was used to determine the lipid peroxidation inhibition effect of E. alba extract (AEEA) as described by Baharum et al., 2014. Briefly, rat liver tissue (2 gm) was sliced and homogenized with $10 \mathrm{~mL} \mathrm{KCl-Tris-HCl} \mathrm{buffer} \mathrm{(} \mathrm{pH}$ 7.2). The reaction solution $(0.5 \mathrm{~mL}$ liver homogenate, $0.2 \mathrm{~mL}$ Tris- $\mathrm{HCl}$ buffer (pH 7.2), $0.1 \mathrm{~mL}$ ascorbic acid, and $0.1 \mathrm{~mL} 4 \mathrm{mM} \mathrm{FeCl}_{2}$ ) and $0.1 \mathrm{~mL}$ of plant extract were taken in tube. The reaction tube was incubated at $37^{\circ} \mathrm{C}$ for $1 \mathrm{~h}$. After incubation $1 \mathrm{~mL}$ $1 \mathrm{~N} \mathrm{HCl}, 0.4 \mathrm{~mL} 9.8 \%$ sodium dodecyl sulfate (SDS), $1.8 \mathrm{~mL}$ distilled water, and $4 \mathrm{~mL} 0.6 \%$ TBA were added to each tube and vigorously shaken. Then, the tubes were placed in a boiling water bath at $100^{\circ} \mathrm{C}$ for $30 \mathrm{~min}$. After cooling, the flocculent precipitate was removed by adding $5 \mathrm{~mL}$-butanol, mixed well, and centrifuged at $9000 \mathrm{rpm}$ for $10 \mathrm{~min}$. The absorbance of the supernatant was measured at $532 \mathrm{~nm}$ [66]. The percentage of lipid peroxidation was measured using following equation:

$$
\begin{aligned}
& \text { Lipid peroxidation inhibition (\%) } \\
& \qquad=\left[\frac{A_{\text {control }}-A_{\text {sample }}}{A_{\text {control }}}\right] \times 100,
\end{aligned}
$$

where $A_{\text {control }}$ is absorbance of control and $A_{\text {sample }}$ is absorbance of sample (extract/ascorbic acid).

2.11. Measurement of Reactive Oxygen Species (ROS). Intracellular ROS level was determined by using peroxidesensitive fluorophore $2^{\prime}, 7^{\prime}$-dichlorodihydrofluorescein diacetate $\left(\mathrm{DCFH}_{2}\right.$-DA) (Sigma). HEK 293 cells were seeded in black bottom 96-well plate and grown up to the confluence. Cells were now treated either with or without different concentrations of AEEA for $24 \mathrm{~h}$. Following treated cells were briefly washed with PBS and incubated with $\mathrm{DCFH}_{2}-\mathrm{DA}$ $10 \mu \mathrm{g} / \mathrm{mL}$ for 30 minutes at $37^{\circ} \mathrm{C}$ under atmosphere pressure, including $5 \% \mathrm{CO}_{2}$. Cells were again washed twice with PBS and fluorescence absorbance was measured at 495/525 nm. The reading was taken on fluorimeter (POLARstar Galaxy; BMG Labtech, Mount Eliza, VIC, Australia).

2.12. Test Animals. CF rats (150-175 gm) were obtained from the National Laboratory Animal Center (NLAC), Central Drug Research Institute, Lucknow, India. The animals were housed in polycarbonate cages with bedding at $25 \pm 2^{\circ} \mathrm{C}$ temperature and $30-60 \%$ relative humidity with a $12 \mathrm{~h}$ light and dark cycle throughout the study period. CF rats were allowed to acclimatize to experimental room conditions for 7 days prior to toxicity study. The animals were fed a standard rodent pellet diet and water ad libitum [67-71].

2.13. Toxicity Study. Healthy CF rats were randomly divided into five groups, with 5 animals per group. One group served as the control and received $1 \%$ gum acacia in distilled water. Four other groups were orally treated by gavage with different doses of AEEA (500, 1000, 1500, and $2000 \mathrm{mg} / \mathrm{kg}$ ) suspended in water with $1 \%$ gum acacia. A toxicity study was carried out as recommended by toxicity evaluation guideline of Schedule $\mathrm{Y}[72]$.
Rats were observed for toxicity symptoms as defined by the Common Toxicity Criteria developed by the Cancer Therapy Evaluation Program with some modification if needed (National Cancer Institute, 1999, Common Toxicity Criteria Version 2.0, Cancer Therapy Evaluation Program). Their body weight changes and food and water intake were recorded on alternate days.

At the end of the study, the animals were fasted overnight, although water was made available ad libitum. They were then anesthetized using diethyl ether for necropsy and blood collection. Blood was collected in two different tubes: one tube containing the anticoagulant EDTA and one tube without anticoagulant for hematological and biochemical examination, respectively. The vital organs of animals were dissected and removed with care. Weight of each organ was taken and examined for macroscopic features.

2.14. Hematological and Biochemical Analysis of Blood. Blood collected in EDTA coated vials was analyzed using MS9 automatic hematology analyzer (Melet Schloesing Ltd., France), shortly after its collection. Blood samples were collected for serum chemistry analysis in tubes lacking anticoagulant and placed at room temperature for at least $90 \mathrm{~min}$ prior to centrifugation; after centrifugation at $1600 \mathrm{~g}$ for $10 \mathrm{~min}$., serum was collected and biochemical parameters were measured using fully automated random access clinical chemistry analyzer (Beckman Synchron CX5, USA).

2.15. Cell Culture. MCF 7, 4T1, MDA-MB-231, HeLa, SKOV-3, SW620, DU145, A549, PANC-1, VERO, and HEK293 cells were obtained from the American Type Culture Collection (ATCC), resuscitated from early passage liquid nitrogen vapor stocks as needed, and cultured according to the supplier's instructions. Cells were routinely inspected microscopically for stable phenotype.

2.16. Cytotoxicity Assay. A standard colourimetric SRB (sulforhodamine B) assay was used for the measurement of cell viability as described before. Briefly, 10,000-20,000 cells (depending on the doubling time of each cell type) were seeded to each well of 96 -well plate in 5\% serum containing growth medium and incubated overnight in $\mathrm{CO}_{2}$ incubator at $37^{\circ} \mathrm{C}$. Adhered cells were then treated with vehicle or AEEA at the required dose. After $48 \mathrm{~h}$ of exposure, cells were fixed with ice-cold 50\% TCA, stained with $0.4 \%$ (w/v) SRB in $1 \%$ acetic acid, washed, and air dried. Bound dye was dissolved in $10 \mathrm{mM}$ Tris base and absorbance was measured at $510 \mathrm{~nm}$ on a plate reader (Epoch Microplate Reader, Biotek, USA). The cytotoxic effects of the compound were calculated as \% of cell viability as per the formula $100-[100-$ (absorbance of treated cells/absorbance of vehicle treated cells) $] \times 100$.

2.17. Detection of Apoptosis. Externalization of phosphatidylserine in apoptotic cells was detected by Annexin V FITC, (green-fluorescent dye). In brief, MCF 7 and MDA-MB-231 cells were grown on coverslips for $24 \mathrm{~h}$ and then treated with different concentration of AEEA for $24 \mathrm{~h}$. Control and treated breast cancer cells were stained with Annexin V FITC and analyzed under fluorescent microscope. 
TABLE 1: Total phenolic and flavonoid contents and the antioxidant activity of AEEA extract along with standard ascorbic acid.

\begin{tabular}{|c|c|c|c|c|c|c|c|c|c|}
\hline \multirow[t]{2}{*}{ Test sample } & \multirow{2}{*}{$\begin{array}{l}\text { TPC }(\mathrm{mg} / \mathrm{g} \\
\mathrm{DW})\end{array}$} & \multirow{2}{*}{$\begin{array}{l}\text { TFC }(\mathrm{mg} / \mathrm{g} \\
\mathrm{DW})\end{array}$} & \multirow{2}{*}{$\begin{array}{l}\text { TAA }(\mathrm{mg} / \mathrm{g} \\
\text { DW) }\end{array}$} & \multicolumn{3}{|c|}{$\begin{array}{l}\% \text { of inhibition at the concentration of } \\
\qquad 25 \mu \mathrm{g} / \mathrm{mL}\end{array}$} & \multicolumn{3}{|c|}{$\mathrm{IC}_{50}(\mu \mathrm{g} / \mathrm{mL})$} \\
\hline & & & & DPPH & NO & LPIA & DPPH & $\mathrm{NO}$ & LPIA \\
\hline AEEA & $31.67 \pm 3.82$ & $91.67 \pm 5.05$ & $173.33 \pm 5.77$ & 25.62 & 21.90 & 19.58 & $\begin{array}{c}136.57 \pm \\
6.83\end{array}$ & $\begin{array}{c}308.73 \pm \\
6.34\end{array}$ & $\begin{array}{c}126.99 \pm \\
8.10\end{array}$ \\
\hline AA & & & $726.57 \pm 9.33$ & 63.75 & 47.77 & 36.36 & $33.5 \pm 1.03$ & $\begin{array}{l}66.27 \pm \\
1.55\end{array}$ & $\begin{array}{l}55.64 \pm \\
3.27\end{array}$ \\
\hline
\end{tabular}

AEEA = alcoholic extract of Eclipta alba, AA = ascorbic acid, TPC = total phenolic contents, TFC = total flavonoid contents, TAA = total antioxidant activity, $\mathrm{DPPH}$ assay $=2,2$-diphenyl-1-picrylhydrazyl assay, $\mathrm{NO}$ assay $=$ nitric oxide assay, and LPIA $=$ lipid peroxidation inhibition activity. Values are mean \pm standard deviation.

2.18. Microscopic Analysis by Hoechst Staining. Morphological changes in the nucleus induced by AEEA treatment were studied by Hoechst 33342 staining. MCF 7 cells $(2 \times$ $10 \%$ well) were seeded in 24 -well plate and after $24 \mathrm{~h}$ of growth cells were treated with different concentration of AEEA for $24 \mathrm{~h}$ and cells were fixed with $4 \%$ paraformaldehyde for $10 \mathrm{~min}$ and then washed with PBS and permeabilized with $4 \%$ paraformaldehyde containing $0.5 \%$ triton X-100 for $30 \mathrm{~min}$ and then stained with Hoechst 33342 stain (Invitrogen $3 \mathrm{mg} / \mathrm{mL}$ ) for $30 \mathrm{~min}$ and images were captured by microscope (Leica).

2.19. Determination of Mitochondrial Membrane Potential $(\Delta \Psi m)$. The changes in the mitochondrial potential were detected by Rhodamine 123, a cationic dye that exhibits potential dependent accumulation in mitochondria, indicated by fluorescence emission shift [73]. In brief, MCF 7 cells grown on coverslips were treated with different concentration of AEEA for $24 \mathrm{~h}$. Control and treated breast cancer cells were stained with Rhodamine 123 and analyzed under fluorescent microscope.

2.20. Wound Healing Assay or Migration Assays. MCF 7 and MDA-MB-231 cells were plated in 6-well plates. Upon reaching $70-80 \%$ confluency, the scratch was performed scraped with a p200 pipette tip. Once the scratch was made the media were removed and replaced with fully supplemented media containing different concentrations of AEEA. Images of the scratch were taken under microscope immediately after the scratch was induced $(0 \mathrm{~h})$ and after $24 \mathrm{~h}$.

2.21. Chemical Analysis by Mass Spectrometry. For chemical characterization mass spectrometric detection was performed on API 4000 Q TRAP mass spectrometer (AB SCIEX Toronto, Canada) equipped with an electrospray ionization (ESI) source. The AEEA was dissolved in 50:50 solution of A, $10 \mathrm{mM}$ ammonium acetate, $0.1 \%$ formic acid in water, and B: 50:50 ACN : $\mathrm{MeOH}$, and infused with Harvard Infusion Pump 11 (Harvard Apparatus, USA) with optimized flow rate of $20 \mu \mathrm{L} /$ minute.

The extract was scanned in both positive and negative ion mode within a range of 100 to $800 \mathrm{~m} / z$, where the positive ion mode showed greater ionization and sensitivity. Data profiling was recorded at a speed of $0.15 \mathrm{~s} / \mathrm{scan}$ and the scanning delay of $0.01 \mathrm{~s}$ during analysis. The main working parameters of the mass spectrometer were (i) ion spray voltage (ISV) 5500, (ii) curtain gas (CUR) 25, and (iii) ion source gases one (GS1) and two (GS2) 10 and quadruple set on unit resolution. Data processing was performed using Analyst version 1.5 software package (SCIEX).

2.22. Statistical Analysis. The data generated during the study was analyzed using one-way ANOVA test and the $p$ value less than 0.05 was considered to be significant.

\section{Results}

3.1. Determination of Total Phenolic Content. Total phenolic content was estimated using a standard curve of gallic acid $\left(R^{2}=0.997\right.$; Figure 1(a)) and expressed as milligrams of gallic acid equivalent (GAE) per gm dry weight. The AEEA sample exhibited the TPC value $31.67 \pm 3.82 \mathrm{mg}$ of GAE/g of extract (Table 1).

3.2. Estimation of Total Flavonoid Contents. Total flavonoid contents (TFC) of the sample were determined using the standard curve of quercetin $\left(R^{2}=0.999\right.$; Figure $\left.1(\mathrm{~b})\right)$. The result was expressed in mg of QUE per gm of dry sample. The total flavonoid contents of AEEA sample were found to be $91.67 \pm 5.05 \mathrm{mg}$ of QUE/g DW (Table 1 ).

3.3. In Vitro Antioxidant Activity and Free Radical Scavenging Power. In order to evaluate the in vitro antioxidant potential of AEEA, various types of assay [i.e., total antioxidant activity (TAA), 1,1-diphenyl-2 picrylhydrazyl (DPPH) radical scavenging, lipid peroxidation inhibition activity (MDA assay), and nitric oxide (NO) free radical scavenging assay] were used in the current study.

3.4. Total Antioxidant Capacity. Total antioxidant activity (TAA) of the samples was obtained from the calibration curve of standard ascorbic acid as shown in Figure 1(c) and expressed as the number of equivalents of ascorbic acid (AAE). The AEEA sample showed the total antioxidant activity with a value $173.33 \pm 5.77 \mathrm{mg}$ equivalent of ascorbic acid (compared to standard ascorbic acid $726.57 \pm 9.33 \mathrm{mg}$ GAE per g DW) (Table 1).

3.5. DPPH Radical Scavenging Activity. The antioxidant scavenging capacity of plant extract (AEEA) was determined using the DPPH free radical scavenging assay. The antioxidant potential of the samples with the standard antioxidant 


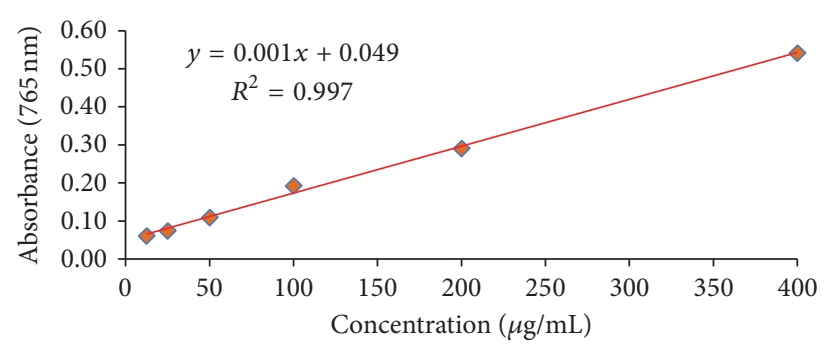

(a)

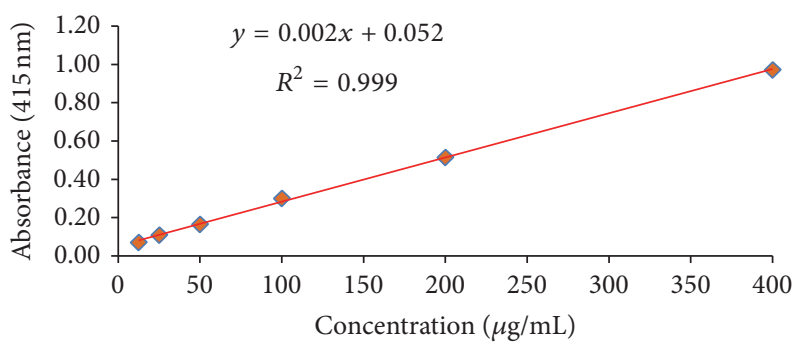

(b)

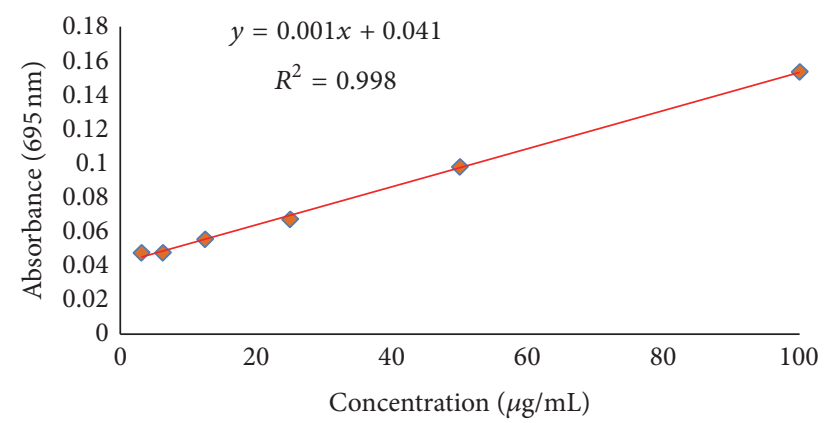

(c)

FIGURE 1: Calibration curve of standards: gallic acid (a), quercetin (b), and ascorbic acid (c) (each point $\left(R^{2}\right.$ values) represents the mean data set of $n=3$ ).

ascorbic acid was evaluated using the parameter $\mathrm{IC}_{50}$. During the test, the degree of decolourization of DPPH from purple to yellow colour indicates the scavenging efficiency of the extracts [74]. The sample (AEEA) along with ascorbic acid revealed the highest scavenging activity of $25.62 \%$ and $63.75 \%$ at the concentration of $25 \mu \mathrm{g} / \mathrm{mL}$ with $\mathrm{IC}_{50}$ value of $136.57 \pm$ 6.83 and $33.5 \pm 1.03 \mu \mathrm{g} / \mathrm{mL}$, respectively (Table 1 ). Therefore, it is reported that the smaller $\mathrm{IC}_{50}$ values show the higher antioxidant activity of the plant extracts [62], because the flavonoids and tannins are phenolic compounds and plant phenolics are a major group of compounds that serve as free radical scavengers [75]. However, the in vitro antioxidant capacity of extract (AEEA) was found to be lower $(p<0.05)$ than of standard ascorbic acid.

3.6. Nitric Oxide Scavenging Activity. Nitric oxide scavenging activity was performed against the sample (AEEA) along with the standard ascorbic acid. The sample (AEEA) along with ascorbic acid exhibited the maximal percentage inhibition (21.90\% and $47.77 \%$ ) at the concentration of $25 \mu \mathrm{g} / \mathrm{mL}$ with $\mathrm{IC}_{50}$ value of $308.73 \pm 6.34$ and $66.27 \pm 1.55 \mu \mathrm{g} / \mathrm{mL}$, respectively (Table 1).

3.7. Lipid Peroxidation Inhibition Activity. Lipid peroxidation inhibition activity was measured in vitro by determining the production of malondialdehyde (MDA) and related compounds in rat liver homogenate [76]. The lipid peroxidation occurs in nonpolar region of the biological membranes and produced the free radicals that lead to various human diseases including cancer [77]. Thus, the inhibition of lipid peroxidation is an indicator of therapeutic potential of plant extracts. The anti-lipid peroxidation activity of the sample along with standard ascorbic acid is illustrated in Table 1. The sample (AEEA) along with ascorbic acid showed the maximal percentage inhibition activity $(19.58 \%$ and $36.36 \%)$ at the concentration of $25 \mu \mathrm{g} / \mathrm{mL}$ with $\mathrm{IC}_{50}$ value of $126.99 \pm 8.10$ and $55.64 \pm 3.27 \mu \mathrm{g} / \mathrm{mL}$, respectively (Table 1 ). The results suggest that the AEEA sample was found with a good antilipid peroxidation activity (i.e., inhibition of MDA formation) but less effective than ascorbic acid.

3.8. Effect of AEEA on Intracellular ROS Level. ROS are produced inside the cells under various stress conditions. High level of ROS caused damage to cell and thus was responsible for occurrence of various diseases [78, 79]. Natural products which have potential to reduce the ROS level of normal cells were very useful in treatment and prevention of many diseases [80-83]. In the present study, we determined the intracellular ROS levels in HEK-293 cells by $2^{\prime}, 7^{\prime}$-dichlorodihydrofluorescein diacetate $\left(\mathrm{DCFH}_{2}-\mathrm{DA}\right)$. $\mathrm{DCFH}_{2}$-DA was hydrolyzed inside the cells by esterases to form nonfluorescent $\mathrm{DCFH}_{2}$, which subsequently are oxidized by intracellular ROS and produce fluorescence. Here, HEK-293 cells were treated with different concentrations of AEEA, and after $24 \mathrm{~h}$ ROS level was determined. Results of this study indicate that AEEA reduces the intracellular ROS levels in concentration dependent manner (Figure 2).

3.9. Antiproliferative Effect of AEEA on the Growth of Different Cancer Cell Lines. In this study, we investigated the dose dependent in vitro cytotoxicity of AEEA on seven different cancer cell lines MDA-MB-231 (breast), HeLa (cervical), SK-OV-3 (ovary), SW620 (colon), DU145 (prostate), A549 (lung), and PANC-1 (pancreatic), belonging to seven different cancer types. Interestingly, we found AEEA to exhibit cytotoxic effect in all the cancer cell lines but it 


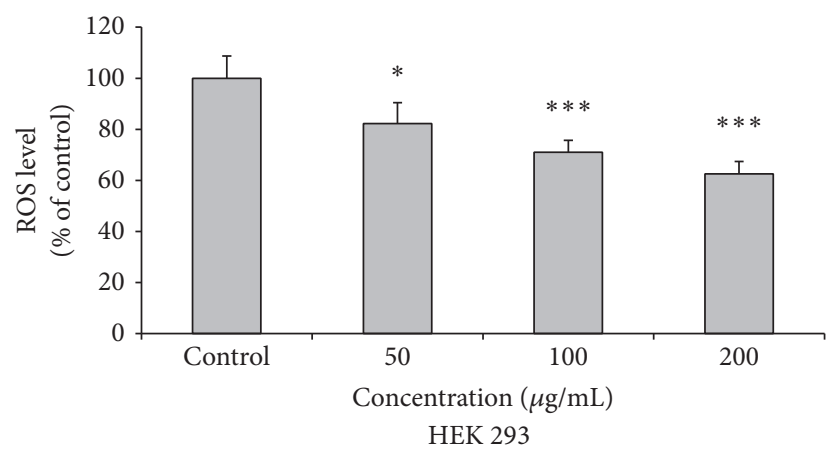

FIgure 2: Intracellular ROS level of HEK 293 cells. Cells are treated with different concentration of AEEA for $24 \mathrm{~h}$. Results are represented as mean $\pm \mathrm{SD}$. Statistical significance determined as compared to control $(0.05 \geq p)$. * represents $p \leq 0.05 ; * * *$ represents $p \leq 0.001$.

is most potent in inducing cytotoxic effects against breast cancer cells line (Figure 3(a)). Representative phase contrast microscopic images of vehicle or treated $(400 \mu \mathrm{g} / \mathrm{mL}$ of AEEA for $48 \mathrm{hr}$ ) cells of seven different cancers showed a clear morphological change. Cells were found to be shrink in size with ruffling and blebbing at cell membranes, suggesting the cells undergoing apoptosis (Figure 3(b)). Further, to test its selective cytotoxicity against cancer cells, we exploited the standard SRB assay to evaluate the cytotoxic effects of AEEA on human breast cancer cell line MCF 7, mouse breast cancer cell line 4T1, and normal epithelial cell line of African green monkey Vero. In our efficient efforts, we observed that AEEA is potently cytotoxic to breast cancer cells, but its toxicity is very minimal to nontumorigenic epithelial cells Vero, implying the nontoxic nature of AEEA (Figure 4).

3.10. Detection of Apoptosis Using the Annexin V FITC. One of the earliest signs of apoptosis is the loss of plasma membrane integrity. In the cell undergoing apoptosis, membrane phospholipid phosphatidylserine (PS) is translocated from the inner surface to outer surface of the plasma membrane [84]. Annexin $\mathrm{V}$ is a $35-36 \mathrm{kDa} \mathrm{Ca}{ }^{2+}$-dependent phospholipid-binding protein with high affinity for PS, which can bind to exposed apoptotic cell surface PS. Annexin V can be conjugated to fluorochromes while retaining its high affinity for PS and thus serves as a sensitive probe for identification of early and late apoptotic cells. In present study MCF 7 and MDA-MB-231 were treated with different concentrations of AEEA for $24 \mathrm{~h}$ and then stained with Annexin V FITC for $30 \mathrm{~min}$ and observed under fluorescence microscope. Here we show that green fluorescence (Annexin V FITC) was increased dose dependently which represented that AEEA causes the translocation of phospholipid phosphatidylserine (PS) to the outer surface of the plasma membrane and thus is responsible for the onset of an early stage of apoptosis in both MCF 7 and MDA-MB-231 (Figure 5).

3.11. Hoechst 33342 Staining to Determine the Morphological Changes in Nucleus. Hoechst 33342 is membrane permeable blue fluorescent dye used for visualization of nuclear morphology changes and apoptotic body formation that are characteristics of apoptosis [85]. After staining with Hoechst 33342 stain, live cells are visualized with homogeneous light blue nuclei when observed under fluorescence microscope. Cells undergoing apoptosis display a bright blue colour after staining due to karyopyknosis and chromatin condensation $[86,87]$. In present study Hoechst 33342 staining was performed to reveal the apoptosis inducing activity of AEEA in MCF 7 cell line. Results of this study confirmed the increase in fluorescence due to chromatin condensation in MCF 7 cells as compared to vehicle control in dose dependent manner (Figure 6). These results indicated that AEEA could induce apoptosis in breast cancer cell line.

3.12. Determination of Mitochondrial Membrane Potential $(\Delta \Psi m)$. Loss in mitochondrial membrane potential is a crucial event of cell signaling pathway that leads to apoptosis. During the course of apoptosis, there is a decrease in mitochondrial membrane potential causing release of cytochrome $c$ from mitochondrial intermembrane space. Release of cytochrome $c$ thus initiated the downstream signaling of apoptosis. Rhodamine 123 is a fluorescent dye used to indicate the loss of mitochondrial membrane potential. In normal condition it permeabilized inside the mitochondria and emits green fluorescence. When decrease in mitochondrial membrane potential occurred, dye translocated outside the mitochondria. Hence, the loss of potential will result in loss of the dye and therefore the fluorescence intensity when viewed under microscope $[88,89]$. After treatment of breast cancer cells with AEEA, the loss of fluorescence was observed in a dose dependent manner (Figure 7).

3.13. Wound Healing Assay or Migration Assays. A wound healing assay was performed to observe the effect of AEEA on the migration ability of breast cancer cells. MCF 7 and MDA-MB-231 were treated with different concentrations of AEEA, and after $24 \mathrm{~h}$ cell migration status was determined under the microscope. Results of this study show that wound was almost healed in control group, but in treated groups inhibition was observed in both cells. In case of MCF 7 cells, migration of cells is inhibited at lower concentration of $100 \mu \mathrm{g} / \mathrm{mL}$ and increases dose dependently. Concentration of $400 \mu \mathrm{g} / \mathrm{mL}$ of AEEA almost completely inhibits the migrations of cells (Figure 8). Migration of MDA-MB-231 cells was also inhibited at a lower concentration of $100 \mu \mathrm{g} / \mathrm{mL}$. However, migration inhibition of AEEA was less effective in MDA-MB-231 cells as compared to MCF 7 cells at lower concentration. On the other hand, migration of MDA-MB231 cells was almost completely inhibited at the concentration of $400 \mu \mathrm{g} / \mathrm{mL}$ similar to the case of MCF 7 cells (Figure 8). The $\%$ of open area (scratch) was quantified with TScratch software (ETH Zürich).

\subsection{Acute Toxicity Study}

3.14.1. General Observations. In present study effect of oral administration of AEEA was observed and summarized in Table 1. Observations of this study revealed that oral 


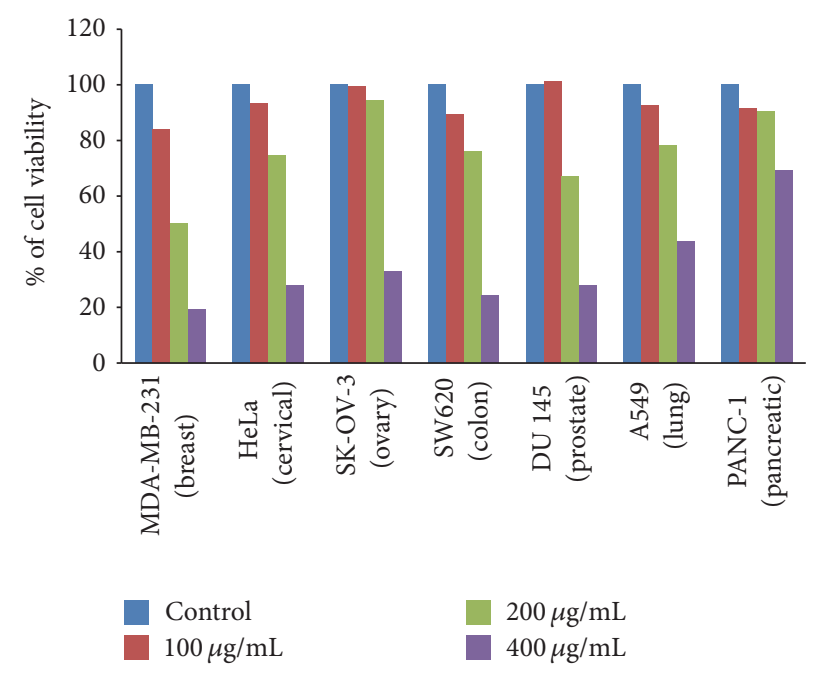

(a)
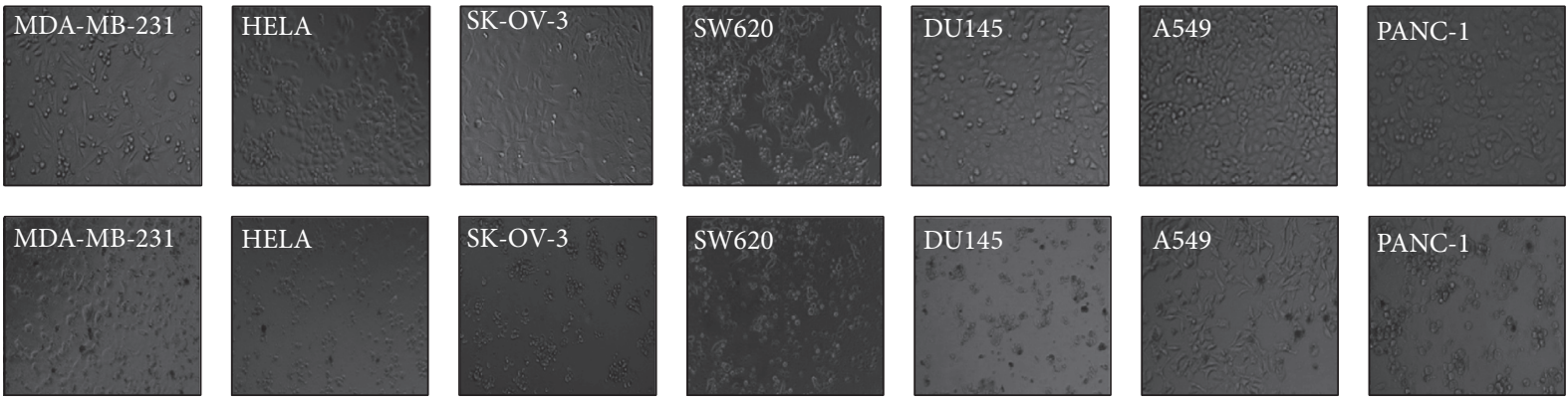

(b)

Figure 3: AEEA induced growth inhibition in different cancer cell lines. MDA-MB-231 (breast), HeLa (cervical), SK-OV-3 (ovary), SW620 (colon), DU145 (prostate), A549 (lung), and PANC-1 (pancreatic) were treated with different concentrations of AEEA for 48 h and cytotoxicity was measured as described in Materials and Methods. Percentage cell viability was plotted in graphs (a). Brightfield microscopy. Effects of AEEA on the morphological changes in different cancer cells after $24 \mathrm{~h}$ treatment $(400 \mu \mathrm{g} / \mathrm{mL})$ were monitored by phase contrast microscopy (b).

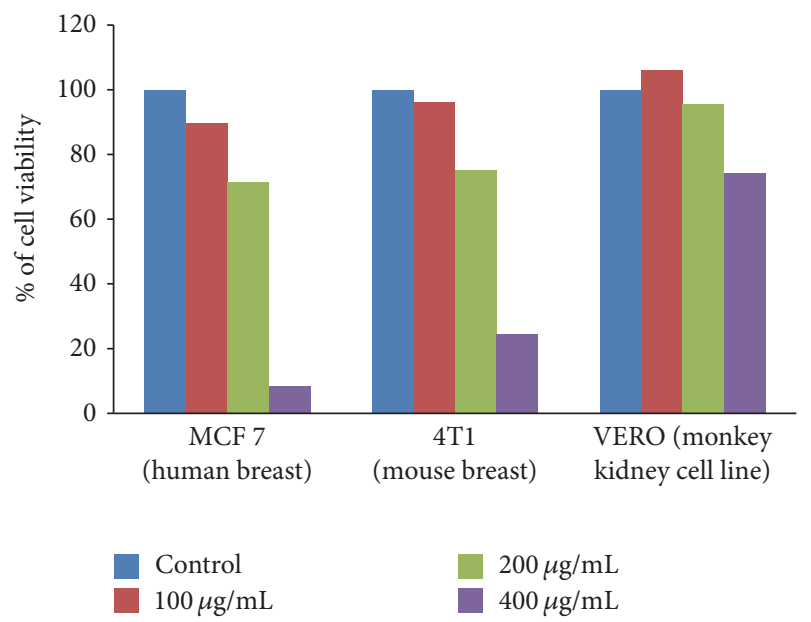

FIGURE 4: Cytotoxic effects of AEEA on human breast cancer cell line MCF 7, mouse breast cancer cell line 4T1, and normal epithelial cell line of African green monkey Vero. MCF 7, 4T1, and Vero cells were treated with different concentrations of AEEA for $48 \mathrm{~h}$ and cytotoxicity was measured as described in Materials and Methods. administration of AEEA up to $2000 \mathrm{mg} / \mathrm{kg}$ body weight does not produce any sign of toxicity in both sexes. Body weight does not show any significant difference between control and treated groups in case of both sexes.

Biochemical and hematological parameters of control and treated groups were analyzed and results were summarized in Tables 2, 3, 4, 5, and 6. Results analysis suggested that the oral administration of AEEA does not produce any sign of toxicity. Biochemical parameters ALT, AST, ALP, and TBIL are the markers of hepatotoxicity, and CREA and BUN are the markers of nephrotoxicity. Analysis of these parameters shows that AEEA does not produce any adverse effect on liver and kidney function. Statistical analysis of blood parameters was carried out and results indicate no significant differences between control and treated groups. Macroscopic analysis of major vital organs was performed and the results suggested that no significant difference was observed in colour, texture, and size treated groups in comparison to control group.

3.14.2. Chemical Characterization of Eclipta alba Extract. Identification of chemical constituent of AEEA was carried 

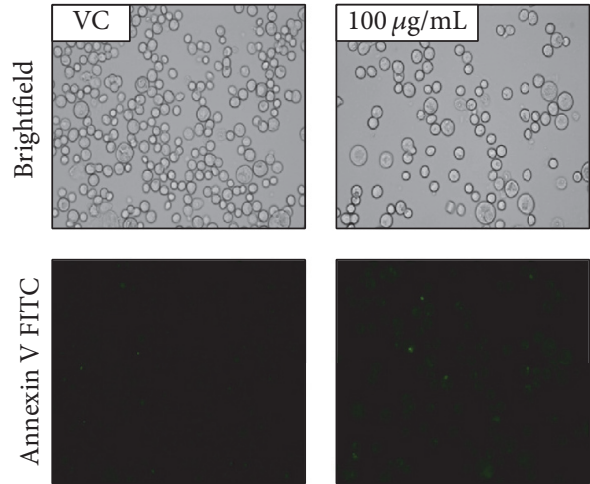

MCF 7
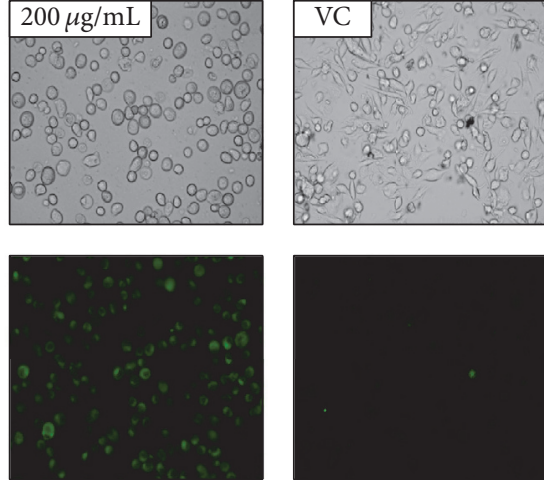
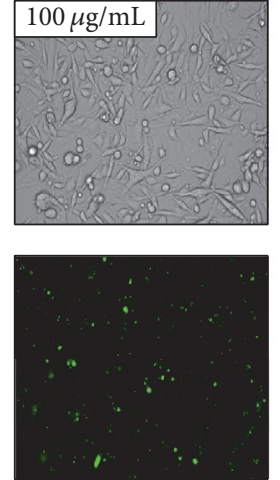

MDA-MB-231
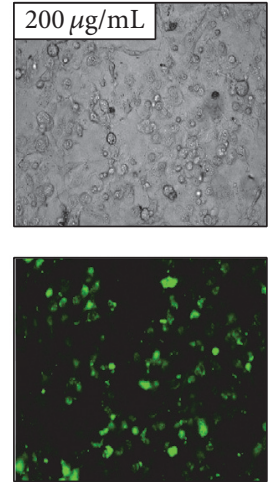

FIGURE 5: Detection of apoptosis in AEEA treated MDA-MB-231 using the Annexin V FITC. MCF 7 and MDA-MB-231 cells were treated with different concentrations of AEEA for $24 \mathrm{~h}$ and stained with Annexin V FITC following standard protocol and observed under fluorescence microscope.
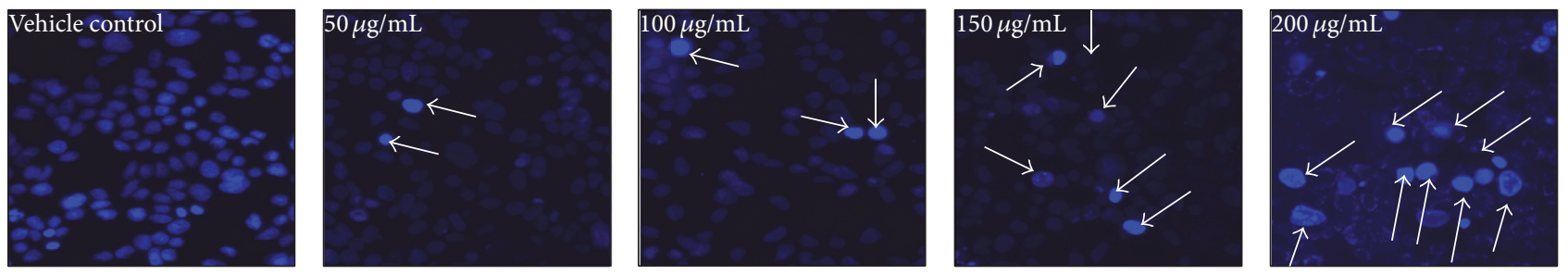

MCF 7

FIGURE 6: Detection of DNA damage by AEEA induced apoptosis in tumor cells by Hoechst 33342 staining. MCF 7 cells were seeded in $24-$ well culture plate and allowed to grow for $24 \mathrm{~h}$. After treatment of $24 \mathrm{~h}$ with different concentrations of Eclipta alba extract cells were stained with Hoechst 33342 following standard protocol and observed under fluorescence microscopy.

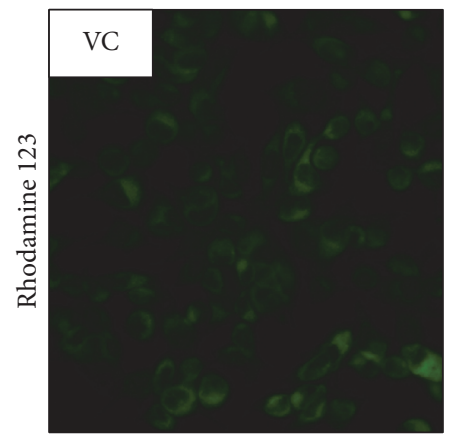

(a)

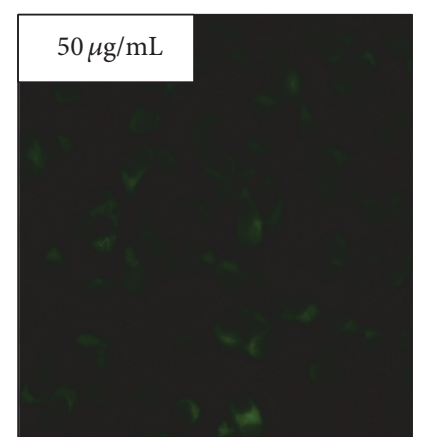

MCF 7

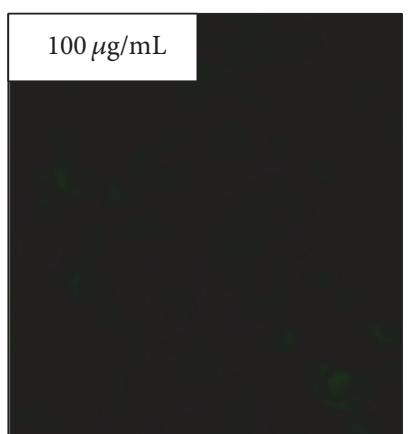

(c)

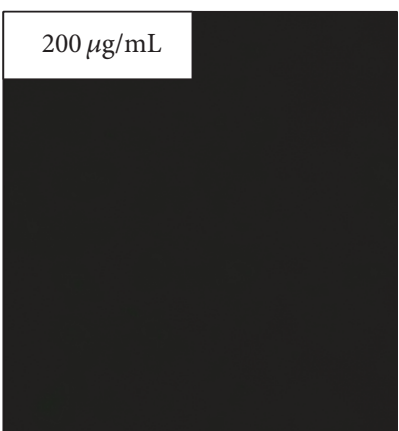

(d)

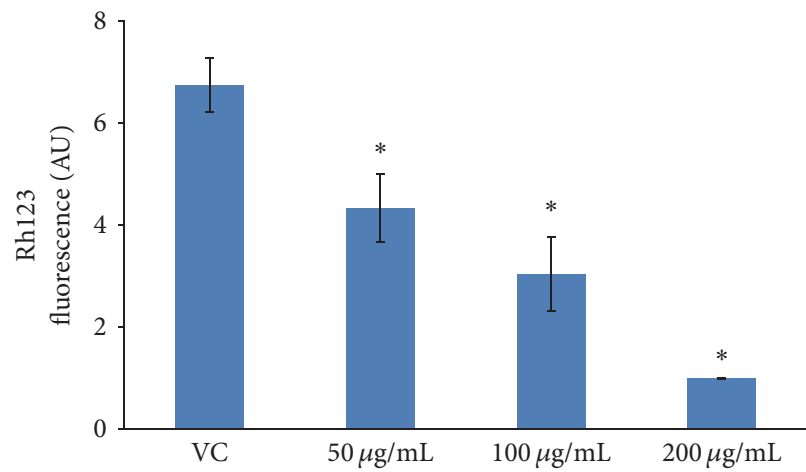

FiguRE 7: Determination of mitochondrial membrane potential $(\Delta \Psi m)$. Rhodamine 123 (RH-123), a mitochondria specific fluorescent dye which stains live cells, is used to determine the mitochondrial membrane potential by measuring fluorescence intensity under microscope. MCF 7 cells were treated with different concentrations of AEEA for $24 \mathrm{~h}$ and stained with Rhodamine 123 following standard protocol and observed under fluorescence microscopy. (a) Control (without treatment); (b-d) treatment with various concentrations of Eclipta alba extract. * represents $p \leq 0.05$. 
TABle 2: Observation for toxicity symptoms as defined in the Common Toxicity Criteria developed by the Cancer Therapy Evaluation Program (National Cancer Institute, 1999, Common Toxicity Criteria Version 2.0, Cancer Therapy Evaluation Program).

\begin{tabular}{|c|c|c|c|c|c|}
\hline & \multirow[t]{2}{*}{ Observation } & \multicolumn{2}{|c|}{ Control group } & \multicolumn{2}{|c|}{$\begin{array}{c}\text { Test groups } \\
(500 \mathrm{mg} / \mathrm{kg} \mathrm{B} . \text { Wt., } \\
1000 \mathrm{mg} / \mathrm{kg} \mathrm{B} . \text { Wt., } \\
1500 \mathrm{mg} / \mathrm{kg} \mathrm{B} \text {. Wt., and } \\
2000 \mathrm{mg} / \mathrm{kg} \mathrm{B} . \text { Wt. })\end{array}$} \\
\hline & & Male & Female & Male & Female \\
\hline 1 & Skin and fur & Normal & Normal & Normal & Normal \\
\hline 2 & Eyes & Normal & Normal & Normal & Normal \\
\hline 3 & $\begin{array}{l}\text { Mucous } \\
\text { membrane }\end{array}$ & Normal & Normal & Normal & Normal \\
\hline 4 & $\begin{array}{c}\text { Behavioural } \\
\text { patterns }\end{array}$ & Normal & Normal & Normal & Normal \\
\hline 5 & Salivation & Normal & Normal & Normal & Normal \\
\hline 6 & Lethargy & Normal & Normal & Normal & Normal \\
\hline 7 & Sleep & Normal & Normal & Normal & Normal \\
\hline 8 & Diarrhea & Normal & Normal & Normal & Normal \\
\hline 9 & Coma & $\mathrm{NO}$ & NO & NO & $\mathrm{NO}$ \\
\hline 10 & Tremors & $\mathrm{NO}$ & $\mathrm{NO}$ & $\mathrm{NO}$ & $\mathrm{NO}$ \\
\hline 11 & $\begin{array}{l}\text { Vomiting and } \\
\text { hematemesis } \\
\text { (vomiting } \\
\text { blood) }\end{array}$ & $\mathrm{NO}$ & $\mathrm{NO}$ & $\mathrm{NO}$ & $\mathrm{NO}$ \\
\hline 12 & $\begin{array}{l}\text { Hematochezia } \\
\text { (bloody stools) }\end{array}$ & NO & NO & $\mathrm{NO}$ & NO \\
\hline 13 & Loss of appetite & $\mathrm{NO}$ & NO & NO & $\mathrm{NO}$ \\
\hline 14 & $\begin{array}{l}\text { Dysphagia } \\
\text { (inability to } \\
\text { swallow) }\end{array}$ & $\mathrm{NO}$ & NO & $\mathrm{NO}$ & NO \\
\hline 15 & Constipation & NO & $\mathrm{NO}$ & $\mathrm{NO}$ & NO \\
\hline
\end{tabular}

$\mathrm{NO}=$ not observed.

TABLE 3: Hematology results on day 15 of oral gavage administration of $500,1000,1500$, and $2000 \mathrm{mg} / \mathrm{kg} \mathrm{B}$. Wt. of AEEA to male CF rats. No statistically significant differences were seen between the control group and the test group [T-RBC = total red blood cells; Hgb = haemoglobin; $\mathrm{MCV}=$ mean corpuscular volume; $\mathrm{HCT}=$ haematocrit; $\mathrm{MCH}=$ mean corpuscular haemoglobin; $\mathrm{MCHC}=$ mean corpuscular haemoglobin concentration; $\mathrm{WBC}=$ white blood cells; RDW = red cell distribution width; MPV = mean platelet volume; PDW = platelet distribution width; PLT $=$ platelet $]$.

\begin{tabular}{lccccccc}
\hline & Parameter & Control group & $500 \mathrm{mg} / \mathrm{kg} \mathrm{B}$. Wt. & $1000 \mathrm{mg} / \mathrm{kg} \mathrm{B}$. Wt. & $1500 \mathrm{mg} / \mathrm{kg} \mathrm{B} . \mathrm{Wt}$. & $2000 \mathrm{mg} / \mathrm{kg} \mathrm{B} . \mathrm{Wt}$. & $p$ value \\
\hline 1 & $\mathrm{Hgb}(\mathrm{g} / \mathrm{dL})$ & $12.26 \pm 0.91$ & $12.66 \pm 0.66$ & $12.74 \pm 0.46$ & $12.74 \pm 1.18$ & $11.92 \pm 0.82$ & $\mathrm{NS}$ \\
2 & $\mathrm{~T}-\mathrm{RBC}\left(\times 10^{6} / \mathrm{mm}^{3}\right)$ & $6.69 \pm 0.58$ & $6.85 \pm 0.22$ & $7.06 \pm 0.36$ & $7.15 \pm 0.61$ & $7 \pm 0.64$ & $\mathrm{NS}$ \\
3 & $\mathrm{MCV}\left(\mathrm{micron}^{3}\right)$ & $54.84 \pm 3.03$ & $54.22 \pm 0.87$ & $54.40 \pm 0.4$ & $54.74 \pm 0.66$ & $54.11 \pm 1.28$ & $\mathrm{NS}$ \\
4 & $\mathrm{HCT}(\%)$ & $36.12 \pm 2.16$ & $37.12 \pm 1.06$ & $38.42 \pm 2.06$ & $39.14 \pm 3.54$ & $37.86 \pm 3.6$ & $\mathrm{NS}$ \\
5 & $\mathrm{MCH}(\mathrm{pg})$ & $18.42 \pm 1.07$ & $18.52 \pm 0.73$ & $18.04 \pm 0.43$ & $17.82 \pm 0.48$ & $17.28 \pm 0.19$ & $\mathrm{NS}$ \\
6 & $\mathrm{MCHC}(\mathrm{g} / \mathrm{dL})$ & $34 \pm 1.79$ & $34.12 \pm 0.96$ & $33.22 \pm 0.81$ & $32.54 \pm 0.96$ & $31.73 \pm 1.02$ & $\mathrm{NS}$ \\
7 & $\mathrm{WBC} \times 10^{3}$ & $5.24 \pm 0.53$ & $5.21 \pm 0.93$ & $5.27 \pm 0.39$ & $5.23 \pm 0.52$ & $5.31 \pm 0.36$ & $\mathrm{NS}$ \\
8 & $\mathrm{RDW}$ & $8.34 \pm 0.39$ & $8.66 \pm 0.42$ & $8.12 \pm 0.39$ & $8.12 \pm 0.29$ & $8.06 \pm 0.47$ & $\mathrm{NS}$ \\
9 & $\mathrm{MPV}$ & $4.62 \pm 0.61$ & $5.32 \pm 0.19$ & $5.1 \pm 0.07$ & $5.27 \pm 0.31$ & $5.06 \pm 0.5$ & $\mathrm{NS}$ \\
10 & $\mathrm{PDW}$ & $8.28 \pm 1.22$ & $9.10 \pm 0.37$ & $8.98 \pm 0.26$ & $9.32 \pm 0.36$ & $8.96 \pm 0.46$ \\
11 & $\mathrm{PLT}\left(\times 10^{3} / \mathrm{mm}^{3}\right)$ & $603.5 \pm 216.45$ & $535 \pm 103$ & $481.8 \pm 62.93$ & $537.4 \pm 161.04$ & $489 \pm 181.42$ & $\mathrm{NS}$ \\
\hline
\end{tabular}

NS signifies no statistical differences when the test group is compared to the control group and when the test groups are compared to each other. 

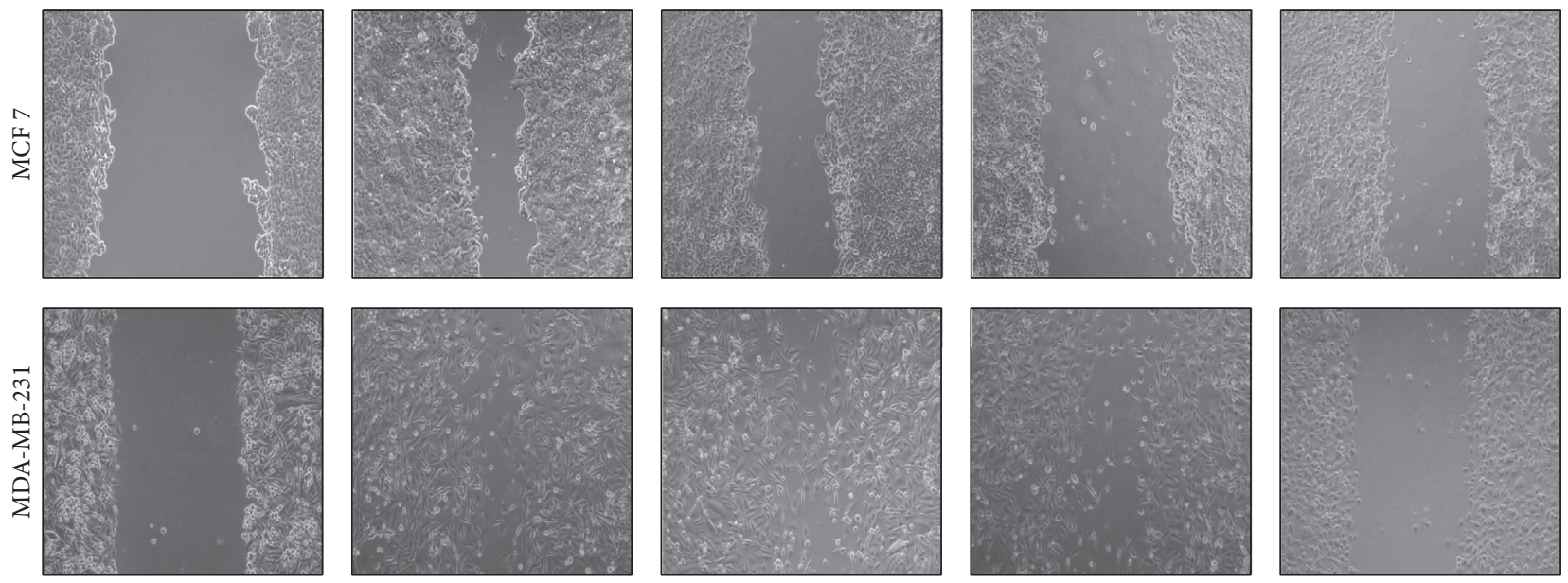

(a) $0 \mathrm{~h}$

(b) VC

(c) $100 \mu \mathrm{g} / \mathrm{mL}$

(d) $200 \mu \mathrm{g} / \mathrm{mL}$

(e) $400 \mu \mathrm{g} / \mathrm{mL}$
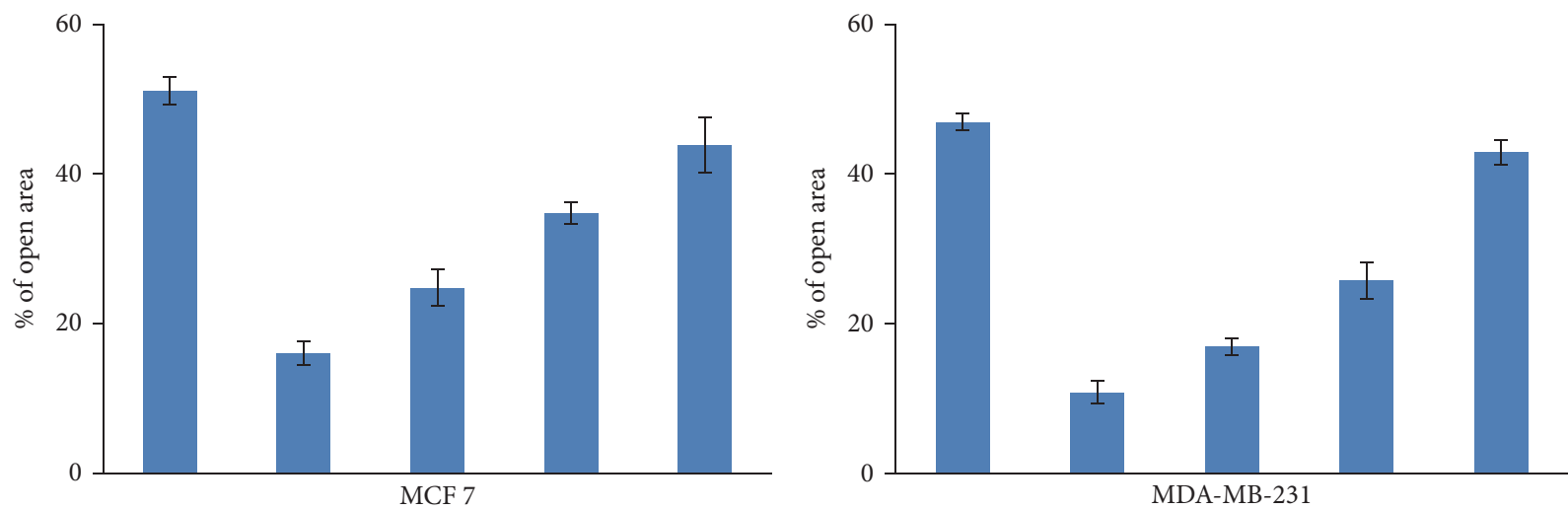

FIGURE 8: Cell migration inhibition by Eclipta alba extract. A scratch wound healing assay was performed on MCF 7 and MDA-MB-231 cells treated with different concentration of AEEA to determine the cell migration ability. (a) Showing scratch wounds in MDA-MD-231 cells at time 0 . (b-e) Representing the status of wound at $24 \mathrm{~h}$ after the initiation of the scratch when the cells were treated with the vehicle control, DMSO (b), or different concentrations of AEEA ( $c-e)$. Wounds were created and AEEA was added immediately. Wounds were evaluated at $24 \mathrm{~h}$ after AEEA administration. ${ }^{*}$ Indicating values that were significantly different $(p<0.05)$ from the DMSO control.

TABLE 4: Hematology results on day 15 of oral gavage administration of 500, 1000, 1500, and $2000 \mathrm{mg} / \mathrm{kg} \mathrm{B}$. Wt. of AEEA to female CF rats. No statistically significant differences were seen between the control group and the test groups [T-RBC = total red blood cells; Hgb = haemoglobin; $\mathrm{MCV}=$ mean corpuscular volume; $\mathrm{HCT}=$ haematocrit $\mathrm{MCH}=$ mean corpuscular haemoglobin; $\mathrm{MCHC}=$ mean corpuscular haemoglobin concentration; WBC = white blood cells; RDW = red cell distribution width; MPV = mean platelet volume; PDW = platelet distribution width; PLT $=$ platelet $]$.

\begin{tabular}{lccccccc}
\hline & Parameter & Control group & $500 \mathrm{mg} / \mathrm{kg} \mathrm{B}$. Wt. & $1000 \mathrm{mg} / \mathrm{kg} \mathrm{B}$. Wt. & $1500 \mathrm{mg} / \mathrm{kg} \mathrm{B.} \mathrm{Wt.}$ & $2000 \mathrm{mg} / \mathrm{kg} \mathrm{B} . \mathrm{Wt}$. & $p$ value \\
\hline 1 & $\mathrm{Hgb}(\mathrm{g} / \mathrm{dL})$ & $13.94 \pm 0.44$ & $13.62 \pm 0.69$ & $14.94 \pm 0.92$ & $14.05 \pm 0.64$ & $14.50 \pm 0.53$ & $\mathrm{NS}$ \\
2 & $\mathrm{~T}-\mathrm{RBC}\left(\times 10^{6} / \mathrm{mm}^{3}\right)$ & $6.9 \pm 0.35$ & $6.7 \pm 0.18$ & $8.03 \pm 1.12$ & $7.22 \pm 0.28$ & $7.79 \pm 0.41$ & $\mathrm{NS}$ \\
3 & $\mathrm{MCV}\left(\mathrm{micron}^{3}\right)$ & $54.64 \pm 1.43$ & $55.64 \pm 0.99$ & $55.56 \pm 1.13$ & $55.33 \pm 1.14$ & $54.32 \pm 0.54$ & $\mathrm{NS}$ \\
4 & $\mathrm{HCT}(\%)$ & $37.7 \pm 1.89$ & $37.28 \pm 1.47$ & $41.8 \pm 4$ & $39.85 \pm 1.21$ & $42.3 \pm 2.39$ & $\mathrm{NS}$ \\
5 & $\mathrm{MCH}(\mathrm{pg})$ & $20.16 \pm 0.75$ & $20.3 \pm 0.8$ & $19.34 \pm 0.98$ & $19.5 \pm 1.3$ & $18.64 \pm 0.73$ & $\mathrm{NS}$ \\
6 & $\mathrm{MCHC}(\mathrm{g} / \mathrm{dL})$ & $36.78 \pm 0.39$ & $36.52 \pm 0.79$ & $34.8 \pm 1.94$ & $35.23 \pm 1.55$ & $34.36 \pm 1.21$ & $\mathrm{NS}$ \\
7 & $\mathrm{WBC} \times 10^{3}$ & $5.15 \pm 0.39$ & $4.85 \pm 0.36$ & $5.32 \pm 0.32$ & $4.86 \pm 1.47$ & $5.38 \pm 0.54$ & $\mathrm{NS}$ \\
8 & $\mathrm{RDW}$ & $8.4 \pm 0.37$ & $8.06 \pm 0.45$ & $8.4 \pm 0.4$ & $8.35 \pm 0.65$ & $8.58 \pm 0.45$ & $\mathrm{NS}$ \\
9 & $\mathrm{MPV}$ & $5.26 \pm 0.09$ & $5.28 \pm 0.22$ & $5.06 \pm 0.18$ & $5.15 \pm 0.06$ & $5.32 \pm 0.19$ & $\mathrm{NS}$ \\
10 & $\mathrm{PDW}$ & $9.44 \pm 0.67$ & $9.62 \pm 0.72$ & $9.24 \pm 0.32$ & $9.15 \pm 0.1$ & $9.36 \pm 0.27$ \\
11 & $\mathrm{PLT}\left(\times 10^{3} / \mathrm{mm}^{3}\right)$ & $387.6 \pm 105.98$ & $450.6 \pm 91.73$ & $490.2 \pm 50.08$ & $507.4 \pm 55.08$ & $519 \pm 89.29$ & $\mathrm{NS}$ \\
\hline
\end{tabular}

NS signifies no statistical differences when the test group is compared to the control group and when the test groups are compared to each other. 
TABLE 5: Result of serum biochemical analysis on day 15 of oral gavage administration of 500, 1000, 1500, and 2000 mg/kg B. Wt. of AEEA to male CF rats. NS represents the no statistical differences, when the test groups were compared to the control group.

\begin{tabular}{lcccccccccccc}
\hline & \multirow{2}{*}{ Parameter } & \multicolumn{2}{c}{ Control group } & \multicolumn{2}{c}{$500 \mathrm{mg} / \mathrm{kg}$ B. Wt. } & \multicolumn{2}{c}{$1000 \mathrm{mg} / \mathrm{kg}$ B. Wt. } & \multicolumn{2}{c}{$1500 \mathrm{mg} / \mathrm{kg}$ B. Wt. } & \multicolumn{2}{c}{$2000 \mathrm{mg} / \mathrm{kg} \mathrm{B}$. Wt. } \\
& & Mean & \pm SD & Mean & \pm SD & Mean & \pm SD & Mean & \pm SD & Mean & \pm SD & value \\
\hline 1 & UREA & 22.88 & 3.054 & 25.78 & 1.761 & 25.56 & 2.101 & 27.38 & 5.622 & 26.06 & 2.9381 & NS \\
2 & ALT & 72.94 & 6.697 & 63.56 & 5.792 & 61.02 & 11.654 & 62.04 & 12.858 & 57.22 & 6.4943 & NS \\
3 & AST & 221.55 & 16.38 & 224.65 & 28.28 & 193.00 & 37.281 & 173.66 & 15.344 & 175.12 & 14.30 & NS \\
4 & ALP & 964.1 & 532.617 & 1035.08 & 425.288 & 741.02 & 291.594 & 704.74 & 416.34 & 667.74 & 145.962 & NS \\
5 & TG & 41.5 & 9.738 & 45.84 & 14.800 & 27.74 & 6.459 & 38.44 & 17.787 & 43.24 & 9.660 & NS \\
6 & TCHO & 56.9 & 10.840 & 54.64 & 4.437 & 55.94 & 11.316 & 62.54 & 12.002 & 61.04 & 5.152 & NS \\
7 & TP & 6.916 & 0.375 & 7.084 & 0.564 & 6.722 & 0.469 & 7.008 & 0.607 & 6.92 & 0.571 & NS \\
8 & ALB & 3.072 & 0.331 & 2.912 & 0.193 & 3.064 & 0.083 & 3.05 & 0.062 & 2.94 & 0.191 & NS \\
9 & GLU & 136.06 & 23.874 & 127 & 57.043 & 157.54 & 74.582 & 188.78 & 65.466 & 164.04 & 20.346 & NS \\
10 & Ca & 9.43 & 1.110 & 9.978 & 0.353 & 9.996 & 0.621 & 10.492 & 0.414 & 9.6 & 0.626 & NS \\
11 & IP & 9.246 & 1.270 & 8.184 & 0.835 & 8.052 & 1.234 & 8.914 & 0.532 & 7.216 & 0.734 & NS \\
12 & TBIL & 0.17 & 0.065 & 0.154 & 0.03 & 0.134 & 0.032 & 0.178 & 0.070 & 0.112 & 0.028 & NS \\
13 & CREA & 0.67 & 0.081 & 0.604 & 0.103 & 0.62 & 0.083 & 0.654 & 0.055 & 0.622 & 0.034 & NS \\
14 & BUN & 10.66 & 1.411 & 12.022 & 0.819 & 11.906 & 0.990 & 12.762 & 2.629 & 12.152 & 1.375 & NS \\
\hline
\end{tabular}

TABLE 6: Result of serum biochemical analysis on day 15 of oral gavage administration of 500, 1000, 1500, and 2000 mg/kg B. Wt. of AEEA to female CF rats. NS represents the no statistical differences, when the test groups were compared to the control group.

\begin{tabular}{ccccccccccccc}
\hline & \multirow{2}{*}{ Parameter } & \multicolumn{2}{c}{ Control group } & \multicolumn{2}{c}{$500 \mathrm{mg} / \mathrm{kg}$ B. Wt. } & \multicolumn{2}{c}{$1000 \mathrm{mg} / \mathrm{kg}$ B. Wt. } & \multicolumn{2}{c}{$1500 \mathrm{mg} / \mathrm{kg}$ B. Wt. } & \multicolumn{2}{c}{$2000 \mathrm{mg} / \mathrm{kg}$ B. Wt. } \\
& & Mean & \pm SD & Mean & \pm SD & Mean & \pm SD & Mean & \pm SD & Mean & \pm SD & \multicolumn{2}{c}{$p$ value } \\
\hline 1 & UREA & $\mathbf{3 0 . 2 4}$ & 3.079 & $\mathbf{3 0 . 3 8}$ & 3.928 & $\mathbf{3 3 . 4 8}$ & 3.679 & $\mathbf{3 4 . 9 6}$ & 5.646 & $\mathbf{3 0 . 9 2}$ & 1.855 \\
2 & ALT & $\mathbf{5 8 . 8 0}$ & 17.86 & $\mathbf{5 6 . 3 8}$ & 12.41 & $\mathbf{5 6 . 8 6}$ & 5.54 & $\mathbf{5 3 . 4 6}$ & 6.72 & $\mathbf{5 7 . 9 0}$ & 5.97 & NS \\
3 & AST & $\mathbf{2 2 7 . 2}$ & 53.05 & $\mathbf{2 0 1 . 6}$ & 43.38 & $\mathbf{2 1 7 . 2}$ & 46.69 & $\mathbf{1 8 3 . 5}$ & 29.34 & $\mathbf{1 8 5 . 2}$ & 24.32 & NS \\
4 & ALP & $\mathbf{6 6 0 . 6}$ & 107.5 & $\mathbf{5 9 0 . 4}$ & 98.89 & $\mathbf{6 0 8 . 3}$ & 91.49 & $\mathbf{5 8 8 . 5}$ & 124.4 & $\mathbf{6 7 5 . 5}$ & 100.7 & NS \\
5 & TG & $\mathbf{1 0 5 . 3}$ & 26.00 & $\mathbf{1 0 4 . 2}$ & 24.40 & $\mathbf{1 1 8 . 8}$ & 53.82 & $\mathbf{1 3 4 . 6}$ & 25.77 & $\mathbf{1 0 4 . 5}$ & 9.02 & NS \\
6 & TCHO & $\mathbf{6 7 . 0 0}$ & 14.56 & $\mathbf{6 5 . 3 8}$ & 3.181 & $\mathbf{6 8 . 7 0}$ & 6.785 & $\mathbf{6 7 . 9 2}$ & 7.093 & $\mathbf{6 8 . 6 0}$ & 4.658 & NS \\
7 & TP & $\mathbf{7 . 0 8}$ & 0.356 & $\mathbf{6 . 9 1 4}$ & 0.622 & $\mathbf{7 . 4 8 0}$ & 0.493 & $\mathbf{7 . 6 6 4}$ & 0.444 & $\mathbf{7 . 2 4 0}$ & 0.327 & NS \\
8 & ALB & $\mathbf{3 . 3 6 0}$ & 0.103 & $\mathbf{3 . 3 5 4}$ & 0.190 & $\mathbf{3 . 5 2 0}$ & 0.205 & $\mathbf{3 . 5 5 0}$ & 0.232 & $\mathbf{3 . 5 0 8}$ & 0.124 & NS \\
9 & GLU & $\mathbf{1 0 2 . 4}$ & 26.65 & $\mathbf{1 2 3 . 4}$ & 28.76 & $\mathbf{1 2 3 . 2 0}$ & 31.75 & $\mathbf{1 3 2 . 9 0}$ & 58.95 & $\mathbf{1 2 8 . 8 0}$ & 46.80 & NS \\
10 & Ca & $\mathbf{9 . 0 6 0}$ & 0.468 & $\mathbf{8 . 7 8 3}$ & 0.345 & $\mathbf{9 . 3 4 8}$ & 0.910 & $\mathbf{9 . 9 2 8}$ & 0.749 & $\mathbf{9 . 7 2 6}$ & 0.352 & NS \\
11 & IP & $\mathbf{1 0 . 5 2}$ & 0.540 & $\mathbf{1 0 . 4 6}$ & 1.645 & $\mathbf{1 1 . 3 4}$ & 3.065 & $\mathbf{1 1 . 3 9}$ & 1.564 & $\mathbf{1 1 . 3 8}$ & 1.477 & NS \\
12 & TBIL & $\mathbf{0 . 0 7 5}$ & 0.001 & $\mathbf{0 . 0 7 8}$ & 0.026 & $\mathbf{0 . 0 7 7}$ & 0.022 & $\mathbf{0 . 0 6 8}$ & 0.023 & $\mathbf{0 . 0 7 4}$ & 0.011 & NS \\
13 & CREA & $\mathbf{0 . 6 8 2}$ & 0.076 & $\mathbf{0 . 7 0}$ & 0.078 & $\mathbf{0 . 7 1 2}$ & 0.150 & $\mathbf{0 . 7 7 4}$ & 0.040 & $\mathbf{0 . 6 7 2}$ & 0.037 & NS \\
14 & BUN & $\mathbf{1 4 . 0 9}$ & 1.432 & $\mathbf{1 4 . 1 6}$ & 1.825 & $\mathbf{1 5 . 6 1}$ & 1.698 & $\mathbf{1 6 . 2 9}$ & 2.64 & $\mathbf{1 4 . 4 2}$ & 0.874 & NS \\
\hline
\end{tabular}

out using mass spectrometry. Several compounds of AEEA were reported in various scientific literatures [345-349]. A combined analysis was done using mass spectrometric data and literature, to construct the final list of identified compounds. The result was shown in Table 7 and Figure 9.

\section{Discussion}

The role of medicinal plants as a source for medicine has been recognized since ancient time [90-92]. Although a major scientific and technological advancement has occurred in an area of combinatorial chemistry, medicinal plants form the basis for many of the drugs currently in commercial use or in development phase [93-95]. They are helping us to find out totally new chemical classes of therapeutic agents and novel mechanisms of action. Several compounds isolated from plants are currently used for the treatment of cancer and other diseases $[5,90]$.

Eclipta alba is a well-known plant of ethnomedicinal significance in the Indian subcontinent. The Ayurvedic pharmacopoeia of India considers the plant as hepatoprotective [96]. In the present study, anti-breast cancer activity of AEEA was carried out in nonmetastatic human MCF 7, metastatic human MDA-MB-231, and metastatic mouse 4T 1 cell lines and results suggested that AEEA shows concentration dependent growth inhibition in each cell line.

Apoptosis is genetically controlled programmed cell death, which takes place during the process of embryonic development, under pathological conditions, as in maintenance of tissue homeostasis, and in aging. The phenomenon 
TABLE 7: Summary of compounds found in extract of AEEA.

\begin{tabular}{|c|c|c|}
\hline \multicolumn{3}{|c|}{ Compounds of Eclipta alba extract } \\
\hline Sl number & Compounds & Mol. Wt. \\
\hline 1 & 2-Methylbutanal oxime & 101 \\
\hline 2 & Catechol & 110 \\
\hline 3 & Uracil & 112 \\
\hline 4 & Phenyl ethylamine & 122 \\
\hline 5 & Nicotinic acid & 123.12 \\
\hline 6 & 4-Hydroxybenzoic acid & 138.13 \\
\hline 7 & 3,4-Dihydroxybenzoic acid & 154.13 \\
\hline 8 & Dihydrocarveol & 154.28 \\
\hline 9 & L-Nicotine & 162.26 \\
\hline 10 & Gallic acid & 170 \\
\hline 11 & Catechol derivative & 190 \\
\hline 12 & Caryophyllene oxide & 220.39 \\
\hline 13 & Coumestan & 236.23 \\
\hline 14 & Apigenin & 270.25 \\
\hline 15 & Butein & 272.27 \\
\hline 16 & $\alpha$-Terthienyl methanol & 278.44 \\
\hline 17 & Indolylmethyl glucosinolate & 283 \\
\hline 18 & Luteolin & 286.25 \\
\hline 19 & Testosterone & 288.47 \\
\hline 20 & 2-Terthiophene-5-carboxylic acid & 292.42 \\
\hline 21 & Demethylwedelolactone & 302.25 \\
\hline 22 & Wedelolactone & 315.1 \\
\hline 23 & Tyramine $\beta$ xanthine & 330 \\
\hline 24 & Gallic acid hexoxide & 332 \\
\hline 25 & Quercetin derivative & 347 \\
\hline 26 & Catechin derivative & 352 \\
\hline 27 & Quercetin derivative & 358 \\
\hline 28 & 16-Methoxytabersonine & 367 \\
\hline 29 & Stigmasterol & 384.71 \\
\hline 30 & $\beta$-Sitosterol & 414 \\
\hline 31 & $\beta$-Amyrin & 426.8 \\
\hline 32 & Hypophyllanthin & 430 \\
\hline 33 & Apigenin-7-O-glucoside & 432.41 \\
\hline 34 & Epicatechin & 442 \\
\hline 35 & Quercetin-3-rhamnoside & 448 \\
\hline 36 & Cynaroside & 448.41 \\
\hline 37 & Catechin derivative & 458 \\
\hline 38 & Demethylwedelolactone 7-glucoside & 462.39 \\
\hline 39 & Galloyl-isorhamnetin & 468 \\
\hline 40 & Echinocystic acid & 472.78 \\
\hline 41 & Caulophyllogenin & 488.78 \\
\hline 42 & Myoinositol & 492 \\
\hline
\end{tabular}

of apoptosis is characterized by specific morphologic features, including loss of plasma membrane asymmetry and attachment, plasma membrane blebbing, condensation of the cytoplasm and nucleus, and internucleosomal cleavage of DNA [84].

Morphological observation was performed to detect whether the cytotoxic effect was related to apoptosis, and results suggested that treatment of breast cancer cells with AEEA causes cell shrinkage, ruffling, and blebbing of cell membrane, which are the important features of apoptosis. Fluorescent microscopic analysis of breast cancer cells treated with AEEA was carried out to observe the externalization of phosphatidylserine; a key feature of early apoptosis was observed using Annexin V FITC, which binds with phosphatidylserine and gives green fluorescence. Here, we find out that treated cells were more evident of apoptosis than control. Treatment of AEEA also results in plasma membrane disintegration, chromatin condensation, and apoptosis mediated cell death, as evident by the fluorescent microscopic analysis with propidium iodide staining. Furthermore, study of breast cancer cells stained with Hoechst 33342 was performed, and results confirmed that treatment of AEEA causes karyopyknosis and chromatin condensation in nucleus, which further results in programmed cell death. Collectively from the results of microscopy it was confirmed that AEEA induces the apoptosis mediated cell death in treated breast cancer cells.

In addition to being the source of energy that sustained the life under aerobic conditions, mitochondria can also be the source of cell signals leading to apoptosis. Several mitochondrial proteins are directly associated with this signaling event. Decline in mitochondrial membrane potential causes release of signals that initiate apoptotic cell death [97-99]. Loss in mitochondrial membrane potential was determined by using Rhodamine 123, which is a positively charged fluorescent dye. In present study loss in fluorescence was observed due to externalization of Rhodamine 123 from mitochondrial matrix and revealed that decrease in mitochondrial membrane potential occurred in AEEA treated cells dose dependently, which subsequently initiated a cascade leading to apoptosis.

In course of metastasis, cancer was spread beyond the place of origin into the other parts of body. Recurrence and metastasis of breast cancer after initial diagnosis and treatment are one of the major challenges for current therapeutic methods [100]. Prevention of metastasis is very crucial for success of breast cancer therapy and survival of patients after diagnosis and treatment. Here, we investigated the migration inhibition potential of AEEA and results suggested that it has potentially inhibited the migration of breast cancer cell lines.

Safety evaluation of AEEA was done in HEK-293 cells and $\mathrm{CF}$ rat to investigate the possible toxic effect of extract. In vitro safety evaluation in HEK-293 cells shows that it does not induce any significant toxicity. AEEA was also tested for its effects in in vivo system. Here no significant change in body weight, food and water intake, behaviour, or mortality was observed as compared with control group. Macroscopic parameters of vital organs also do not show any significant differences in treated groups.

In present study, serum biochemical parameters were analyzed and they do not show any statistical significant difference between control and treated groups in both sexes. Alanine aminotransferase (ALT), aspartate aminotransferase (AST), alkaline phosphatase (ALP), and total bilirubin are the liver function markers, used to evaluate the liver function. In values of liver function markers no significant change was 


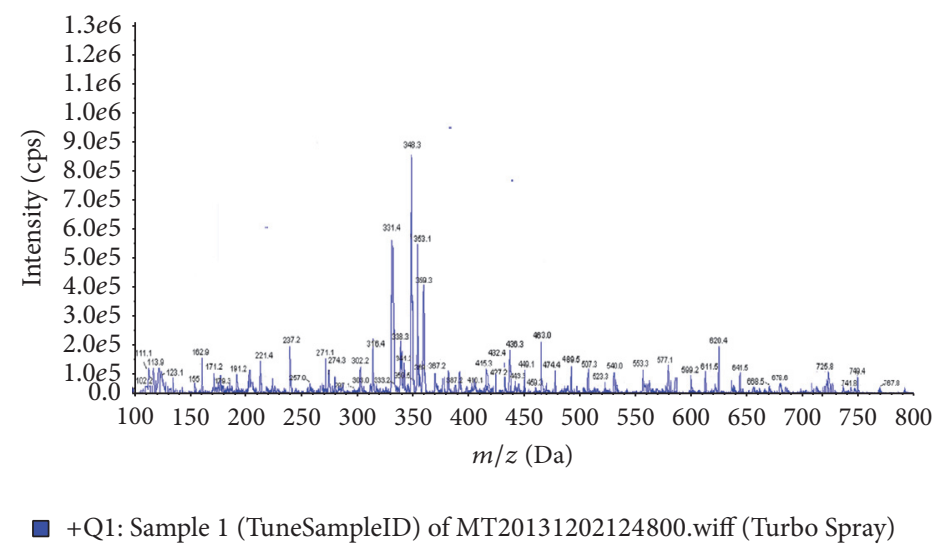

FIGURE 9: Mass fingerprinting chromatogram of SIE in positive ion $(M+1)$ mode.

observed among control and treated groups. Serum biochemical parameter creatinine (CRTEA), blood urea nitrogen (BUN), and UREA are used to evaluate the kidney function. Results suggested that they do not show any significant change. Triglycerides (TG), total cholesterol (TCHO), total protein (TP), albumin (ALB), total glucose (GLU), calcium (Ca), and inorganic phosphorus (IP) levels in serum were evaluated. These values represent the general metabolism of body. They also show no significant difference and dose response [101]. In conclusion, analysis of serum biochemical parameters shows that AEEA does not produce any adverse effect on liver, kidney, and general metabolic function of the body. Hematological parameters were observed in present study to find out the effect of AEEA on blood. No significant changes between different dose groups were observed in male as well as in female rats. Thus, AEEA oral administration does not show any adverse effect on hematological parameters.

Chemical analysis of AEEA was performed by mass spectrometry and result has been summarized in Table 7 and Figure 9. Table 7 consists of a list of identified compounds. Further, a literature survey on identified compounds has been performed by using citation source like Pubmed and Web of Science and result shows that a majority of identified compounds exhibit anticancer as well as antioxidant activity. Result of literature survey shows that a majority of identified compounds exhibit anticancer as well as antioxidant activity (Supporting Information: Table 1 in Supplementary Material available online at http://doi.org/10.1155/2017/9094641). Thus, we have concluded that presence of these compounds in Eclipta alba extract leads to its anticancer and antioxidant activity. Outcomes of chemical analysis will be helpful in further research for identification and synthesis of bioactive compounds responsible for antioxidant, anti-breast cancer, and protective activity.

At moderate concentrations reactive oxygen species (ROS) act as secondary messenger and participate in a variety of intracellular signaling pathways. An excessive and/or sustained increase in ROS production has been implicated in the pathogenesis of cancer, neurodegenerative diseases, atherosclerosis, ischemia/reperfusion injury, obstructive sleep apnea, rheumatoid arthritis, diabetes mellitus, and other diseases. Thus, free radical and ROS scavenging activity of plant extracts are very useful for protection of normal cells from oxidative damage [102]. Protective activity of AEEA for free radicals was confirmed by antioxidant activity assays. Furthermore, protective role of AEEA in cellular system was determined, and it significantly reduces the level of ROS in HEK-293 cells in concentration dependent manner. This activity is also helpful to mitigate the side effects during cancer therapy. Thus, it is to be expected that use of AEEA as an anti-breast cancer agent will not cause oxidative damage to normal cells, which are observed in case of doxorubicin, paclitaxel, and docetaxel [103].

A number of research studies in which Eclipta alba extract was subjected to in vivo treatment measured the level of glutathione (GSH), a tripeptide containing an active thiol group in the form of a cysteine residue, providing protection against reactive oxygen and nitrogen species [104]. Bhaskar et al., 2014, Mansoorali et al., 2012, Hemalakshmi et al., 2012, Arun et al., 2011, Parmar et al., 2010, and so forth described the effect of Eclipta alba extract treatment on level of GSH, and results of these studies reported that level of GSH was decreased during the oxidative stress. However, after that the treatment level was significantly increased. So, it was concluded that Eclipta alba extract helps to restore the level of GSH during oxidative stress and hence played a crucial role to provide protection against oxidative damage [105-109].

\section{Conclusion}

Our results provided a new insight into antioxidant and anti-breast cancer activity and toxicological evaluation of AEEA. Our data demonstrated that AEEA provides protection against free radical and intracellular ROS. Moreover, toxicological evaluation of AEEA provides us with crucial information which is helpful to understand its effect on in vivo system. The anti-breast cancer study finding demonstrated that AEEA induces apoptosis mediated cell death. These results suggested that AEEA could be a candidate for a novel anticancer agent and may have a potential to be used in complementary and alternative medicine for the treatment of breast cancer and other types of cancer. 


\section{Competing Interests}

The authors declare that there is no conflict of interests regarding the publication of this paper.

\section{Authors' Contributions}

Navneet Kumar Yadav, Rakesh Kumar Arya, and Kapil Dev contributed equally to this work.

\section{Acknowledgments}

Research in the authors' laboratory is supported by different CSIR funds like BSC0106, UGC fellowship grants (to Rakesh Kumar Arya, Navneet Kumar Yadav), ICMR fellowship grants (Chetan Sharma, Kapil Dev), and CSIR fellowship grants (Zakir Hossain). Institutional (CSIR-CDRI) communication number for this article is 9345 .

\section{References}

[1] R. Siegel, C. Desantis, and A. Jemal, "Colorectal cancer statistics, 2014,” CA: A Cancer Journal for Clinicians, vol. 64, no. 2, pp. 104117, 2014.

[2] T. Yi, B. Zhai, Y. Yu et al., "Quantitative phosphoproteomic analysis reveals system-wide signaling pathways downstream of SDF-1/CXCR4 in breast cancer stem cells," Proceedings of the National Academy of Sciences of the United States of America, vol. 111, no. 21, pp. E2182-E2190, 2014.

[3] J. Ferlay, I. Soerjomataram, R. Dikshit et al., "Cancer incidence and mortality worldwide: sources, methods and major patterns in GLOBOCAN 2012," International Journal of Cancer, vol. 136, no. 5, pp. E359-E386, 2015.

[4] S. Shetti, C. D. Kumar, N. K. Sriwastava, and I. P. Sharma, "Pharmacovigilance of herbal medicines: current state and future directions," Pharmacognosy Magazine, vol. 7, no. 25, pp. 69-73, 2011.

[5] D. J. Newman and G. M. Cragg, "Natural products as sources of new drugs over the 30 years from 1981 to 2010," Journal of Natural Products, vol. 75, no. 3, pp. 311-335, 2012.

[6] D. J. Newman, G. M. Cragg, and K. M. Snader, "Natural products as sources of new drugs over the period 1981-2002," Journal of Natural Products, vol. 66, no. 7, pp. 1022-1037, 2003.

[7] M. Markman, "Safety issues in using complementary and alternative medicine," Journal of Clinical Oncology, vol. 20, no. 18, pp. 39S-41S, 2002.

[8] Y.-H. Hwang, H. Ha, and J. Y. Ma, "Acute oral toxicity and genotoxicity of Dryopteris crassirhizoma," Journal of Ethnopharmacology, vol. 149, no. 1, pp. 133-139, 2013.

[9] N. Chiranthanut, S. Teekachunhatean, A. Panthong, P. Khonsung, D. Kanjanapothi, and N. Lertprasertsuk, "Toxicity evaluation of standardized extract of Gynostemma pentaphyllum Makino," Journal of Ethnopharmacology, vol. 149, no. 1, pp. 228234, 2013.

[10] K. Chan, "Some aspects of toxic contaminants in herbal medicines," Chemosphere, vol. 52, no. 9, pp. 1361-1371, 2003.

[11] K. V. Ergil, E. J. Kramer, and A. T. Ng, "Chinese herbal medicines," Western Journal of Medicine, vol. 176, no. 4, pp. 275-279, 2002.

[12] J. L. Hartwell, "Plants used against cancer. A survey," Lloydia, vol. 34 , no. 4, pp. 386-425, 1971.
[13] J. G. Graham, M. L. Quinn, D. S. Fabricant, and N. R. Farnsworth, "Plants used against cancer-an extension of the work of Jonathan Hartwell," Journal of Ethnopharmacology, vol. 73, no. 3, pp. 347-377, 2000.

[14] J. L. Hartwell, Plants used Against Cancer, Quarterman Publications, Lawrence, Mass, USA, 1982.

[15] D. Breitkreutz, L. Hlatky, E. Rietman, and J. A. Tuszynski, "Molecular signaling network complexity is correlated with cancer patient survivability," Proceedings of the National Academy of Sciences of the United States of America, vol. 109, no. 23, pp. 9209-9212, 2012.

[16] N. K. Yadav, K. S. Saini, Z. Hossain et al., "Saraca indica bark extract shows in vitro antioxidant, antibreast cancer activity and does not exhibit toxicological effects," Oxidative Medicine and Cellular Longevity, vol. 2015, Article ID 205360, 15 pages, 2015.

[17] Y.-Q. Zhang, X. Mao, Q.-Y. Guo, N. Lin, and S. Li, "Network pharmacology-based approaches capture essence of Chinese herbal medicines," Chinese Herbal Medicines, vol. 8, no. 2, pp. 107-116, 2016.

[18] N. K. Yadav, P. Shukla, A. Omer, and R. K. Singh, "In silico approach to uncover the anti-cancerous activity of certain phyto-compounds," Gene Therapy and Molecular Biology, vol. 15, no. 1, pp. 147-158, 2013.

[19] H. S. Puri, Rasayana: Ayurvedic Herbs for Longevity and Rejuvenation, Taylor \& Francis, London, UK, 2003.

[20] Y. Zhao, L. Peng, W. Lu et al., "Effect of Eclipta prostrata on lipid metabolism in hyperlipidemic animals," Experimental Gerontology, vol. 62, pp. 37-44, 2015.

[21] P. Jian and Z. Taiyan, The Medical Plant Index of China, Science Press, Beijing, China, 1st edition, 1957.

[22] Q.-M. Liu, H.-Y. Zhao, X.-K. Zhong, and J.-G. Jiang, "Eclipta prostrata L. phytochemicals: isolation, structure elucidation, and their antitumor activity," Food and Chemical Toxicology, vol. 50, no. 11, pp. 4016-4022, 2012.

[23] D. L. Ying, "The research progress in chemical constituents, pharmacological effects and clinic application of Eclipta prostrata," China Pharmaceutical Journal, vol. 19, pp. 2876-2878, 2008.

[24] M. Sawant, J. C. Isaac, and S. Narayanan, "Analgesic studies on total alkaloids and alcohol extracts of Eclipta alba (Linn.) Hassk," Phytotherapy Research, vol. 18, no. 2, pp. 111-113, 2004.

[25] R. K. Roy, M. Thakur, and V. K. Dixit, "Hair growth promoting activity of Eclipta alba in male albino rats," Archives of Dermatological Research, vol. 300, no. 7, pp. 357-364, 2008.

[26] V. Rangineni, D. Sharada, and S. Saxena, "Diuretic, hypotensive, and hypocholesterolemic effects of Eclipta alba in mild hypertensive subjects: a pilot study," Journal of Medicinal Food, vol. 10, no. 1, pp. 143-148, 2007.

[27] O. J. F. Lobo, D. Banji, A. R. Annamalai, and R. Manavalan, "Evaluation of antiaggressive activity of Eclipta alba in experimental animals," Pakistan Journal of Pharmaceutical Sciences, vol. 21, no. 2, pp. 195-199, 2008.

[28] V. D. Thakur and S. A. Mengi, "Neuropharmacological profile of Eclipta alba (Linn.) Hassk," Journal of Ethnopharmacology, vol. 102, no. 1, pp. 23-31, 2005.

[29] V. Jadhav, R. Thorat, V. Kadam, and K. Salaskar, "Chemical composition, pharmacological activities of Eclipta alba," Journal of Pharmacy Research, vol. 2, no. 8, pp. 1229-1231, 2009.

[30] P. S. Pandey, K. K. Upadhyay, and D. N. Pandey, "Experimental evaluation of the analgesic property of eclipta alba (L) hassk," Ancient Science of Life, vol. 17, no. 1, pp. 36-40, 1997. 
[31] H. Wagner, B. Geyer, Y. Kiso, H. Hikino, and G. S. Rao, "Coumestans as the main active principles of the liver drugs Eclipta alba and Wedelia calendulacea," Planta Medica, vol. 52, no. 5, pp. 370-374, 1986.

[32] N. Chauhan, D. Singh, and R. M. Painuli, "Screening of bioprotective properties and phytochemical analysis of various extracts of Eclipta alba whole plant," International Journal of Pharmacy and Pharmaceutical Sciences, vol. 4, no. 2, pp. 554560, 2012.

[33] L. S. Chokotia, P. Vashistha, R. Sironiya, and H. Matoli, "Pharmacological activities of Eclipta alba (L.)," International Journal of Research and Development in Pharmacy and Life Sciences, vol. 2, no. 4, pp. 499-502, 2013.

[34] N. M. Mithun, S. Shashidhara, and R. Vivek Kumar, "Eclipta alba (L.) A review on its phytochemical and pharmacological profile," Pharmacologyonline, vol. 1, pp. 345-357, 2011.

[35] V. N. Murthy, B. P. Reddy, V. Venkateshwarlu, and C. K. Kokate, "Antihepatotoxic activity of eclipta alba, tephrosia purpurea and boerhaavia diffusa," Ancient Science of Life, vol. 11, no. 3-4, pp. 182-186, 1992.

[36] B. Singh, A. K. Saxena, B. K. Chandan, S. G. Agarwal, and K. K. Anand, "In vivo hepatoprotective activity of active fraction from ethanolic extract of Eclipta alba leaves," Indian Journal of Physiology and Pharmacology, vol. 45, no. 4, pp. 435-441, 2001.

[37] Y. Han, C. Xia, X. Cheng et al., "Preliminary studies on chemical constituents and pharmacological action of Eclipta prostrata L," Zhongguo Zhong Yao Za Zhi, vol. 23, no. 11, pp. 680-703, 1998.

[38] K. Ma-Ma, N. Nyunt, and K. M. Tin, "The protective effect of Eclipta alba on carbon tetrachloride-induced acute liver damage," Toxicology and Applied Pharmacology, vol. 45, no. 3, pp. 723-728, 1978.

[39] A. K. Saxena, B. Singh, and K. K. Anand, "Hepatoprotective effects of Eclipta alba on subcellular levels in rats," Journal of Ethnopharmacology, vol. 40, no. 3, pp. 155-161, 1993.

[40] B. Singh, A. K. Saxena, B. K. Chandan, S. G. Agarwal, M. S. Bhatia, and K. K. Anand, "Hepatoprotective effect of ethanolic extract of Eclipta alba on experimental liver damage in rats and mice," Phytotherapy Research, vol. 7, no. 2, pp. 154-158, 1993.

[41] D.-I. Kim, S.-H. Lee, J.-H. Choi, H. S. Lillehoj, M.-H. Yu, and G.-S. Lee, "The butanol fraction of Eclipta prostrata (Linn) effectively reduces serum lipid levels and improves antioxidant activities in CD rats," Nutrition Research, vol. 28, no. 8, pp. 550554, 2008.

[42] H. Wagner, B. Geyer, Y. Kiso, H. Hikino, and G. S. Rao, "Coumestans as the main active principles of the liver drugs Eclipta alba and Wedelia calendulacea," Planta Medica, vol. 5, pp. 370374, 1986.

[43] K. Datta, A. T. Singh, A. Mukherjee, B. Bhat, B. Ramesh, and A. C. Burman, "Eclipta alba extract with potential for hair growth promoting activity," Journal of Ethnopharmacology, vol. 124, no. 3, pp. 450-456, 2009.

[44] S. Begum, M. R. Lee, L. J. Gu, M. J. Hossain, H. K. Kim, and C. K. Sung, "Comparative hair restorer efficacy of medicinal herb on nude (Foxn1 ${ }^{\mathrm{nu}}$ ) mice," BioMed Research International, vol. 2014, Article ID 319795, 9 pages, 2014.

[45] S. Begum, M. R. Lee, L. J. Gu, J. Hossain, and C. K. Sung, "Exogenous stimulation with Eclipta alba promotes hair matrix keratinocyte proliferation and downregulates TGF- $\beta 1$ expression in nude mice," International Journal of Molecular Medicine, vol. 35, no. 2, pp. 496-502, 2015.

[46] K. Lirdprapamongkol, J.-P. Kramb, D. Chokchaichamnankit et al., "Juice of Eclipta prostrata inhibits cell migration in vitro and exhibits anti-angiogenic activity in vivo," In Vivo, vol. 22, no. 3 , pp. 363-368, 2008.

[47] H. Chaudhary, V. Dhuna, J. Singh, S. S. Kamboj, and S. Seshadri, "Evaluation of hydro-alcoholic extract of Eclipta alba for its anticancer potential: an in vitro study," Journal of Ethnopharmacology, vol. 136, no. 2, pp. 363-367, 2011.

[48] H. Chaudhary, P. K. Jena, and S. Seshadri, "Evaluation of hydroalcoholic extract of Eclipta alba for its multidrug resistance reversal potential: an in vitro study," Nutrition and Cancer, vol. 65, no. 5, pp. 775-780, 2013.

[49] H. Chaudhary, P. K. Jena, and S. Seshadri, "In vivo evaluation of Eclipta alba extract as anticancer and multidrug resistance reversal agent," Nutrition and Cancer, vol. 66, no. 5, pp. 904913, 2014.

[50] F. Ali, R. Khan, A. Q. Khan, M. A. Lateef, T. Maqbool, and S. Sultana, "Assessment of augmented immune surveillance and tumor cell death by cytoplasmic stabilization of p53 as a chemopreventive strategy of 3 promising medicinal herbs in murine 2stage skin carcinogenesis," Integrative Cancer Therapies, vol. 13, no. 4, pp. 351-367, 2014.

[51] H.-Y. Kim, H. M. Kim, B. Ryu, J.-S. Lee, J.-H. Choi, and D. S. Jang, "Constituents of the aerial parts of Eclipta prostrata and their cytotoxicity on human ovarian cancer cells in vitro," Archives of Pharmacal Research, vol. 38, no. 11, pp. 1963-1969, 2015.

[52] Y. J. Cho, J. H. Woo, J. S. Lee, D. S. Jang, K. T. Lee, and J. H. Choi, "Eclalbasaponin II induces autophagic and apoptotic cell death in human ovarian cancer cells," Journal of Pharmacological Sciences, vol. 132, no. 1, pp. 6-14, 2016.

[53] L.-U. Ling, K.-B. Tan, H. Lin, and G. N. C. Chiu, "The role of reactive oxygen species and autophagy in safingol-induced cell death," Cell Death and Disease, vol. 2, article e129, 2011.

[54] Z.-Y. Li, Y. Yang, M. Ming, and B. Liu, "Mitochondrial ROS generation for regulation of autophagic pathways in cancer," Biochemical and Biophysical Research Communications, vol. 414, no. 1, pp. 5-8, 2011.

[55] H.-U. Simon, A. Haj-Yehia, and F. Levi-Schaffer, "Role of reactive oxygen species (ROS) in apoptosis induction," Apoptosis, vol. 5, no. 5, pp. 415-418, 2000.

[56] L. Castro and B. A. Freeman, "Reactive oxygen species in human health and disease," Nutrition, vol. 17, no. 2, pp. 161-165, 2001.

[57] M. Kapiszewska, E. Soltys, F. Visioli, A. Cierniak, and G. Zajac, "The protective ability of the Mediterranean plant extracts against the oxidative DNA damage. The role of the radical oxygen species and the polyphenol content," Journal of Physiology and Pharmacology, vol. 56, supplement 1, pp. 183-197, 2005.

[58] H. R. Kang, H. J. Kim, H.-J. Suh, O. O. Kwon, K. S. Kim, and J.-S. Kim, "Reactive oxygen species scavenging activities of naturally occurring colorants," Food Science and Biotechnology, vol. 22, no. 1, pp. 225-231, 2013.

[59] S.-T. Chang, J.-H. Wu, S.-Y. Wang, P.-L. Kang, N.-S. Yang, and L.-F. Shyur, "Antioxidant activity of extracts from Acacia confusa bark and heartwood," Journal of Agricultural and Food Chemistry, vol. 49, no. 7, pp. 3420-3424, 2001.

[60] V. Singleton and J. A. Rossi, "Colorimetry of total phenolics with phosphomolybdic-phosphotungstic acid reagents," American Journal of Enology and Viticulture, vol. 16, no. 3, pp. 144-158, 1965.

[61] C.-C. Chang, M.-H. Yang, H.-M. Wen, and J.-C. Chern, "Estimation of total flavonoid content in propolis by two complementary colorimetric methods," Journal of Food and Drug Analysis, vol. 10, no. 3, pp. 178-182, 2002. 
[62] P. Prieto, M. Pineda, and M. Aguilar, "Spectrophotometric quantitation of antioxidant capacity through the formation of a phosphomolybdenum complex: specific application to the determination of vitamin E," Analytical Biochemistry, vol. 269, no. 2, pp. 337-341, 1999.

[63] W. Brand-Williams, M. E. Cuvelier, and C. Berset, "Use of a free radical method to evaluate antioxidant activity," LWT-Food Science and Technology, vol. 28, no. 1, pp. 25-30, 1995.

[64] L. Marcocci, L. Packer, M. T. Droy-Lefaix, A. Sekaki, and M. Gardes-Albert, "Antioxidant action of Ginkgo biloba extract EGb 761," Methods in Enzymology, vol. 234, pp. 462-475, 1994.

[65] R. Srinivasan, M. J. N. Chandrasekar, M. J. Nanjan, and B. Suresh, "Antioxidant activity of Caesalpinia digyna root," Journal of Ethnopharmacology, vol. 113, no. 2, pp. 284-291, 2007.

[66] R. Sreelekshmi, P. Latha, M. Arafat et al., "Anti-inflammatory, analgesic and anti-lipid peroxidation studies on stem bark of Ficus religiosa Linn," Natural Product Radiance, vol. 6, no. 5, pp. 377-381, 2007.

[67] N. Sethi, R. Dayal, and R. K. Singh, "Acute and subacute toxicity study of inhaled methyl isocyanate in Charles Foster rats," Ecotoxicology and Environmental Safety, vol. 18, no. 1, pp. 6874, 1989.

[68] D. Chanda, K. Shanker, A. Pal et al., "Safety evaluation of trikatu, a generic Ayurvedic medicine in Charles Foster rats," Journal of Toxicological Sciences, vol. 34, no. 1, pp. 99-108, 2009.

[69] P. Kumar, A. V. Ranawade, and N. G. Kumar, "Potential probiotic Escherichia coli 16 harboring the Vitreoscilla hemoglobin gene improves gastrointestinal tract colonization and ameliorates carbon tetrachloride induced hepatotoxicity in rats," BioMed Research International, vol. 2014, Article ID 213574, 9 pages, 2014.

[70] M. K. Gautam and R. K. Goel, "Toxicological study of Ocimum sanctum Linn leaves: hematological, biochemical, and histopathological studies," Journal of Toxicology, vol. 2014, Article ID 135654, 9 pages, 2014.

[71] S. Suman, M. Ali, R. Kumar, and A. Kumar, "Phytoremedial effect of Pleurotus cornucopiae (Oyster Mushroom) against Sodium Arsenite Induced Toxicity in Charles Foster Rats," Pharmacology \& Pharmacy, vol. 5, no. 12, pp. 1106-1112, 2014.

[72] Y. Schedule, "Amendment version 2005, Drugs and Cosmetics Rules," 1945.

[73] S. W. Perry, J. P. Norman, J. Barbieri, E. B. Brown, and H. A. Gelbard, "Mitochondrial membrane potential probes and the proton gradient: a practical usage guide," BioTechniques, vol. 50, no. 2, pp. 98-115, 2011.

[74] M. Khatoon, E. Islam, R. Islam et al., "Estimation of total phenol and in vitro antioxidant activity of Albizia procera leaves," BMC Research Notes, vol. 6, no. 1, article 121, 2013.

[75] O. Potterat, "Antioxidants and free radical scavengers of natural origin," Current Organic Chemistry, vol. 1, no. 4, pp. 415-440, 1997.

[76] D. M. Nagmoti, D. K. Khatri, P. R. Juvekar, and A. R. Juvekar, "Antioxidant activity free radical-scavenging potential of Pithecellobium dulce Benth seed extracts," Free Radicals and Antioxidants, vol. 2, no. 2, pp. 37-43, 2012.

[77] W. Takabe, E. Niki, K. Uchida, S. Yamada, K. Satoh, and N. Noguchi, "Oxidative stress promotes the development of transformation: involvement of a potent mutagenic lipid peroxidation product, acrolein," Carcinogenesis, vol. 22, no. 6, pp. 935941, 2001
[78] D. J. Lefer and D. N. Granger, "Oxidative stress and cardiac disease," American Journal of Medicine, vol. 109, no. 4, pp. 315323, 2000.

[79] P. Steer, J. Millgård, D. M. Sarabi et al., "Cardiac and vascular structure and function are related to lipid peroxidation and metabolism," Lipids, vol. 37, no. 3, pp. 231-236, 2002.

[80] V. Di Matteo and E. Esposito, "Biochemical and therapeutic effects of antioxidants in the treatment of Alzheimer's disease, Parkinson's disease, and amyotrophic lateral sclerosis," Curr Drug Target CNS Neurol Disord, vol. 2, no. 2, pp. 95-107, 2003.

[81] M. Gerber, M.-C. Boutron-Ruault, S. Hercberg, E. Riboli, A. Scalbert, and M.-H. Siess, "Food and cancer: state of the art about the protective effect of fruits and vegetables," Bulletin $d u$ Cancer, vol. 89, no. 3, pp. 293-312, 2002.

[82] M. Valko, D. Leibfritz, J. Moncol, M. T. D. Cronin, M. Mazur, and J. Telser, "Free radicals and antioxidants in normal physiological functions and human disease," International Journal of Biochemistry and Cell Biology, vol. 39, no. 1, pp. 44-84, 2007.

[83] A. Barzegar and A. A. Moosavi-Movahedi, "Intracellular ROS protection efficiency and free radical-scavenging activity of curcumin," PLoS ONE, vol. 6, no. 10, Article ID e26012, 2011.

[84] J. F. Kerr, A. H. Wyllie, and A. R. Currie, "Apoptosis: a basic biological phenomenon with wide-ranging implications in tissue kinetics," British Journal of Cancer, vol. 26, no. 4, pp. 239-257, 1972.

[85] S. Yang, Q. Zhao, H. Xiang et al., "Antiproliferative activity and apoptosis-inducing mechanism of constituents from Toona sinensis on human cancer cells," Cancer Cell International, vol. 13, no. 1, article 12, 2013.

[86] J. Wu, W. Yi, L. Jin, D. Hu, and B. Song, "Antiproliferative and cell apoptosis-inducing activities of compounds from Buddleja davidii in Mgc-803 cells," Cell Division, vol. 7, no. 1, article 20, 2012.

[87] X. Xu, X. Gao, L. Jin et al., "Antiproliferation and cell apoptosis inducing bioactivities of constituents from Dysosma versipellis in PC3 and Bcap-37 cell lines," Cell Division, vol. 6, no. 1, article 14, 2011.

[88] B. Chazotte, "Labeling mitochondria with rhodamine 123," Cold Spring Harbor Protocols, vol. 2011, no. 7, pp. 892-894, 2011.

[89] C. Pieme, G. Santosh, E. Tekwu et al., "Fruits and barks extracts of Zanthozyllum heitzii a spice from Cameroon induce mitochondrial dependent apoptosis and Go/G1 phase arrest in human leukemia HL-60 cells," Biological Research, vol. 47, no. 1, article 54, 2014.

[90] A. B. da Rocha, R. M. Lopes, and G. Schwartsmann, "Natural products in anticancer therapy," Current Opinion in Pharmacology, vol. 1, no. 4, pp. 364-369, 2001.

[91] N. R. Farnsworth, O. Akerele, A. S. Bingel, D. D. Soejarto, and Z. Guo, "Medicinal plants in therapy," Bulletin of the World Health Organization, vol. 63, no. 6, pp. 965-981, 1985.

[92] G. M. Cragg, D. J. Newman, and K. M. Snader, "Natural products in drug discovery and development," Journal of Natural Products, vol. 60, no. 1, pp. 52-60, 1997.

[93] M. F. Balandrin, A. D. Kinghorn, and N. R. Farnsworth, PlantDerived Natural Products in Drug Discovery and Development: An Overview, ACS Symposium Series, 1993.

[94] N. R. Farnsworth, “The role of ethnopharmacology in drug development," Ciba Foundation Symposium, vol. 154, pp. 2-21, 1990.

[95] G. M. Cragg and D. J. Newman, "Discovery and development of antineoplastic agents from natural sources," Cancer Investigation, vol. 17, no. 2, pp. 153-163, 1999. 
[96] R. Jahan, A. Al-Nahain, S. Majumder, and M. Rahmatullah, "Ethnopharmacological significance of Eclipta alba (L.) Hassk. (Asteraceae)," International Scholarly Research Notices, vol. 2014, Article ID 385969, 22 pages, 2014.

[97] R. A. Gottlieb, "Mitochondria: execution central," FEBS Letters, vol. 482 , no. 1-2, pp. 6-12, 2000.

[98] X. Wang, "The expanding role of mitochondria in apoptosis," Genes and Development, vol. 15, no. 22, pp. 2922-2933, 2001.

[99] E. Gottlieb, S. M. Armour, M. H. Harris, and C. B. Thompson, "Mitochondrial membrane potential regulates matrix configuration and cytochrome c release during apoptosis," Cell Death and Differentiation, vol. 10, no. 6, pp. 709-717, 2003.

[100] E. A. Musgrove and R. L. Sutherland, "Biological determinants of endocrine resistance in breast cancer," Nature Reviews Cancer, vol. 9, no. 9, pp. 631-643, 2009.

[101] M. A. Costa, J. C. Palazzo de Mello, E. N. Kaneshima et al., "Acute and chronic toxicity of an aqueous fraction of the stem bark of Stryphnodendron adstringens (Barbatimão) in rodents," Evidence-Based Complementary and Alternative Medicine, vol. 2013, Article ID 841580, 9 pages, 2013.

[102] W. Dröge, "Free radicals in the physiological control of cell function," Physiological Reviews, vol. 82, no. 1, pp. 47-95, 2002.

[103] A. Pieniazek, J. Czepas, J. Piasecka-Zelga, K. Gwoådziński, and A. Koceva-Chyła, "Oxidative stress induced in rat liver by anticancer drugs doxorubicin, paclitaxel and docetaxel," Advances in Medical Sciences, vol. 58, no. 1, pp. 104-111, 2013.

[104] V. I. Lushchak, "Glutathione homeostasis and functions: potential targets for medical interventions," Journal of Amino Acids, vol. 2012, Article ID 736837, 26 pages, 2012.

[105] K. P. Mansoorali, T. Prakash, D. Kotresha, K. Prabhu, and N. Rama Rao, "Cerebroprotective effect of Eclipta alba against global model of cerebral ischemia induced oxidative stress in rats," Phytomedicine, vol. 19, no. 12, pp. 1108-1116, 2012.

[106] K. Arun and U. Balasubramanian, "Comparative study on Hepatoprotective activity of Aegle marmelos and Eclipta alba against alcohol induced in albino rats," International Journal of Environmental Sciences, vol. 2, no. 2, p. 389, 2011.

[107] S. R. Parmar, P. H. Vashrambhai, and K. Kalia, "Hepatoprotective activity of some plants extract against paracetamol induced hepatotoxicity in rats," Journal of Herbal Medicine and Toxicology, vol. 4, no. 2, pp. 101-106, 2010.

[108] P. T. V. Hemalakshmi, P. Sriram, and L. N. Mathuram, "Hypoglycemic and antioxidant activities of methanolic extract of Eclipta alba in experimentally induced diabetes mellitus in rats," Tamil Nadu Journal of Veterinary \& Animal Sciences, vol. 8, no. 4, pp. 215-226, 2012.

[109] M. B. A. M. Chintamaneni, "Investigating the role of Eclipta alba on brain antioxidant markers, cognitive performance and acetylcholinesterase activity of rats," International Journal of Pharmaceutical and Phytopharmacological Research, vol. 3, no. 5, pp. 390-394, 2014. 


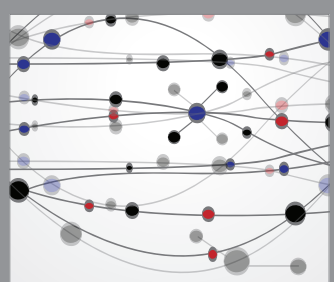

The Scientific World Journal
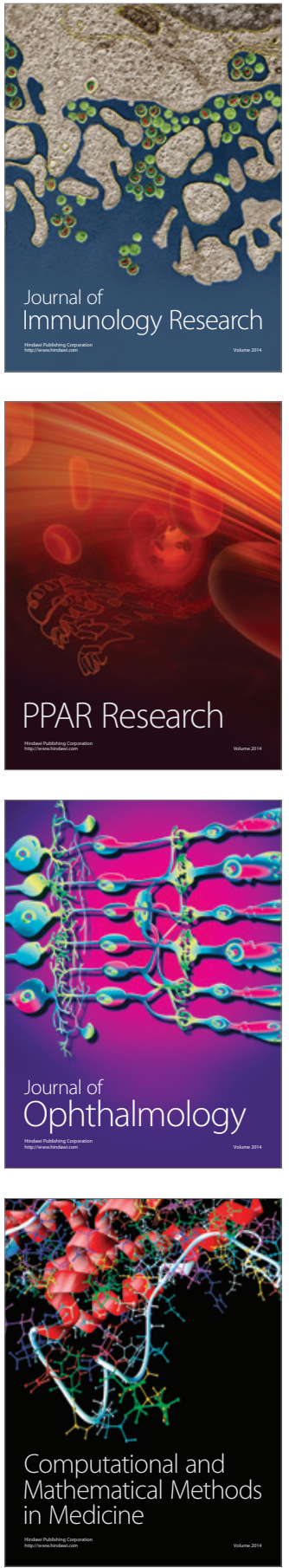

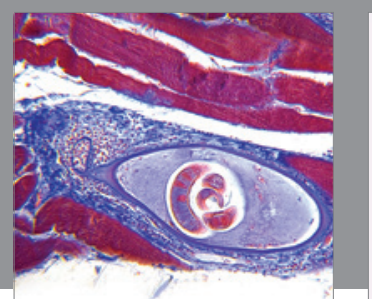

Gastroenterology Research and Practice
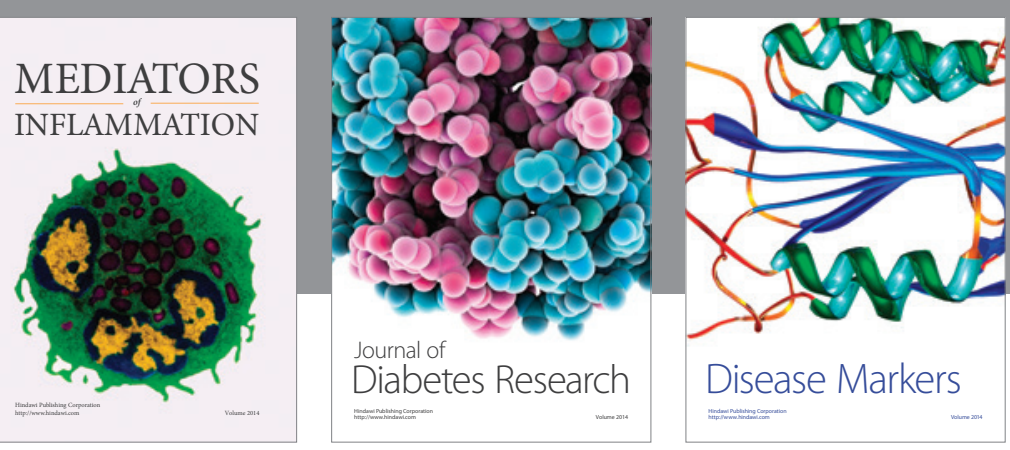

Disease Markers

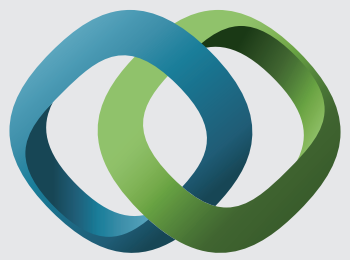

\section{Hindawi}

Submit your manuscripts at

https://www.hindawi.com
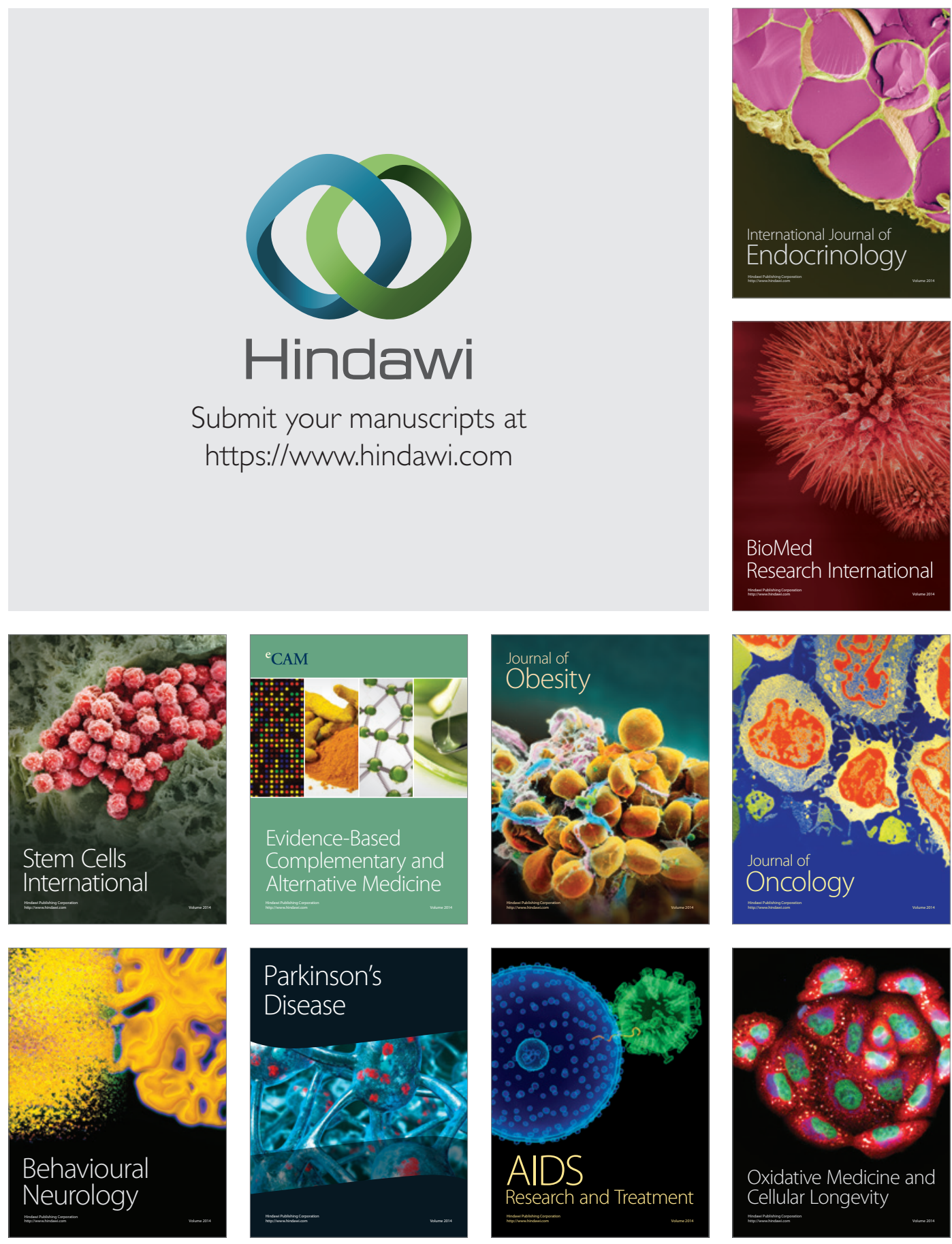